\title{
Fuel Cell Mobile Lighting: A Fuel Cell Market Transformation Project
}

L.E. Klebanoff ${ }^{1}$,*, J.S. Breit ${ }^{2}$, G.S. Roe ${ }^{2}$, T. Damberger ${ }^{3}$, T. Erbel $^{4}$, S.Wingert ${ }^{4}$, B. Coleman ${ }^{4}$, C.J. Radley ${ }^{5}$, J.M. Oros ${ }^{5}$, P. Schuttinger ${ }^{5}$, R. Woolley ${ }^{6}$, H. Ghotb ${ }^{6}$, S. Prey ${ }^{6}$, S. Velinsky ${ }^{7}$, W. White $^{7}$, R. Saunders ${ }^{8}$, C. Saunders ${ }^{8}$, R. Drake ${ }^{9}$, G. Rea ${ }^{9}$, D. Fliess ${ }^{10}$, R. Hooson ${ }^{10}$, W.T Elrick ${ }^{11}$, J. Hamilton ${ }^{11}$, T. Skradski ${ }^{12}$, G. Brown ${ }^{13}$, B. Chao ${ }^{14}$, M. Zelinsky ${ }^{14}$ A. Sorkin ${ }^{15}$, R. McGlaughlin $^{15}$, G. Moreland ${ }^{16}$, R.C. Hanley ${ }^{17}$, M. Koonce ${ }^{18}$, and T.A. Johnson ${ }^{1}$

1. Sandia National Laboratories, 7011 East Avenue, Livermore CA 94551 USA

2. System Concept Center, Boeing Commercial Airplanes, Everett, WA 98203 USA

3. Golden State Energy, 312 West Fourth Street, Carson City, NV 89703 USA

4. Multiquip Inc., 18910 Wilmington Ave., Carson CA 90746 USA

5. Altergy Systems, 140 Blue Ravine Road, Folsom, CA 95630, USA

6. Caltrans Division of Research, Innovation \& System Information Technology Applications Office, 3347 Michelson Drive, Suite 100 Irvine, CA 92612 USA

7. Dept. of Mechanical \& Aerospace Engineering, University of California - Davis One Shields Avenue, Davis, CA 95616 USA

8. Saunders Electric Inc., 9330 Laurel Canyon Blvd., Arleta, California, 91331 USA

9. Stray Light Optical Technologies Inc., 821 S. Lake Road South, Scottsburg, IN 47170 USA

10. City and County of San Francisco, San Francisco International Airport, P.O. Box 8097, San Francisco, CA 94128 USA

11. California Fuel Cell Partnership, 3300 Industrial Blvd., Suite 1000, West Sacramento, CA 95691 USA

12. Lumenworks, 3410 Lakeshore Ave., Suite 201, Oakland CA 94610 USA

13. Luxim Corporation, 3542 Bassett St., Santa Clara, CA 95054 USA

14. Ovonic Hydrogen Systems, 2983 Waterview Dr., Rochester Hills MI, 48309 USA

15. NASA Technology Evaluation for Environmental Risk Mitigation (TEERM) Principal Center, Kennedy Space Center, Florida 32899 USA

16. SRA International, Latham New York, 12110 USA

17. Connecticut Department of Transportation, 2800 Berlin Turnpike, Newington CT 06131 USA.

18. IGX Group Inc., 490 Post Street, Suite \#1700, San Francisco, CA 94102 USA

*Corresponding Author 


\begin{abstract}
We report the results of a project aimed to introduce proton exchange membrane (PEM) hydrogen fuel cell technology into aviation ground support equipment (GSE) and rental construction equipment. The purpose of the project was to design, build, field-test and then commercialize fuel cell equipment that is superior to its diesel counterpart. The commercializing of this hydrogen-based technology will help to start the process of displacing diesel fuel use in aviation GSE and in mobile construction equipment. We describe a hydrogen fuel cell mobile lighting tower $\left(\mathrm{H}_{2} \mathrm{LT}\right)$ that combines hydrogen stored as a high pressure gas, PEM fuel cell technology, and advanced lighting into a single unit with uses in aviation and construction. We assembled a project team of 15 institutional partners combining new technology expertise (hydrogen, fuel cells), equipment mass manufacturing capability (mobile light towers, lighting) and influential end-users to field test the $\mathrm{H}_{2} \mathrm{LT}$ in real-world use in diverse environments. Seed funding provided by Boeing enabled additional funding from the U.S. Department of Energy (DOE) and a preponderance of in-kind contributions from the industrial partners. Prototype units were constructed and field tested in the entertainment industry, at the San Francisco International Airport, at the NASA Kennedy Space Center, with the California Department of Transportation (Caltrans), and with the Connecticut Department of Transportation. The goals of these approximately yearlong field tests were to assess operation of the $\mathrm{H}_{2} \mathrm{LT}$ technology in a wide variety of potentially corrosive environments (cold, wet, hot, humid, salty air) performing a wide variety of tasks, to reduce diesel emissions at these locations, and to help promote hydrogen PEM technology in new influential markets. The $\mathrm{H}_{2} \mathrm{LT}$ proved to be exceptionally durable in these diverse environments, demonstrating the compatibility of PEM fuel cells and highpressure hydrogen storage with the construction equipment application. Results from the field tests are discussed, including system performance (efficiency, duration, durability) and the efficacy of refueling the system by different methods $\left(\mathrm{H}_{2}\right.$ stations, mobile refueling). The $\mathrm{H}_{2} \mathrm{LT}$ system is compared directly to a comparable diesel-fueled light tower with regard to size, performance and emissions. Overall, end users were pleased with the performance of the $\mathrm{H}_{2} \mathrm{LT}$, noting the lack of emissions and exceptionally low noise level. Recommendations for improvement were also collected and will be discussed. Two types of lighting used on the $\mathrm{H}_{2} \mathrm{LT}$ (plasma, LED) were characterized by U.C. Davis in collaboration with Caltrans. LED lighting was found to be the most energy efficient and robust lighting technology for the highly mobile $\mathrm{H}_{2} \mathrm{LT}$ application. The technical "lessons-learned" are reviewed, along with the plans for commercialization of the $\mathrm{H}_{2} \mathrm{LT}$ technology by Multiquip Inc. Finally, the benefits to the industrial participants of the project organization are described.
\end{abstract}




\section{Introduction:}

This paper describes a project to bring hydrogen proton exchange membrane (PEM) fuel cell technology to aviation ground support equipment (GSE) and general construction equipment in the form of a hydrogen fuel cell mobile light tower $\left(\mathrm{H}_{2} \mathrm{LT}\right)$. The project brought together new technology holders, mass manufacturing capability, and end-users to produce a superior zeroemissions commercial product that could be purchased, starting reductions in greenhouse gas (GHG) emissions in the construction equipment and aviation GSE realms.

Hydrogen fuel cell systems have the potential to provide high-efficiency and eventually low-cost power for portable equipment. Keller et al. has reviewed the attributes of hydrogen-based power for zero-emissions transportation technology [1], while also describing the history and worrisome magnitudes of the GHG emission and global climate change problems. PEM fuel cell systems and their use in automotive and portable power technology were recently reviewed by Klebanoff and co-workers [2]. The reader is directed to these references for a full description of hydrogen and PEM fuel cell technology and how hydrogen fuel cells can mitigate global climate change. The use of fuel cell portable construction equipment represents a good early market introduction of fuel cells, thereby supporting fuel cell market growth. The current diesel-based mobile light tower market is approximately 100,000 units in the United States, thus representing a niche market within the construction equipment realm, but a good starting point for introducing fuel cells into construction equipment and aviation GSE.

We begin with a discussion of how the project was initiated by The Boeing Company as well as the formation of the project team consisting of 15 institutional partners spread across industry, state government, and other entities. The elements of the $\mathrm{H}_{2} \mathrm{LT}$ system design are described, and the $\mathrm{H}_{2} \mathrm{LT}$ is directly compared to a comparable diesel-powered light tower with regard to size, performance and emissions. An account is then given of the field-tests in a number of challenging environments meant to test the physical durability and performance of the system, stimulate hydrogen fueling resources at the test sites, reduce diesel emissions at these locations, and promote fuel cell technology in new impactful markets. Finally, we review the design "lessons-learned" from the field-tests (which will fold into the final commercial design), discuss the reception and recognition of the $\mathrm{H}_{2} \mathrm{LT}$ from industry, and the current plans to commercialize the $\mathrm{H}_{2} \mathrm{LT}$ by Multiquip Inc. (MQ).

\section{Project Origin:}

In 2007, Sandia and Boeing collaborated on analyzing the utility of placing a PEM fuel cell onboard a commercial aircraft as a fuel cell emergency power system (FCEPS) [3]. The FCEPS system met the temperature, pressure, power, and volume requirements of the emergency power 
application. Thus the FCEPS could serve as a relatively isolated (and therefore straightforward) point of introduction of fuel cell technology into the aircraft electrical infrastructure.

Following this FCEPS project, and anticipating barriers to getting a new power technology onboard commercial aircraft, Boeing felt it would be useful to gain experience with PEM fuel cells in a situation just off the aircraft, in a piece of aviation GSE on the tarmac. That way, Boeing could assess the technology for reliability, safety and infrastructure (fueling) requirements in an aviation environment not as challenging as the "on-board" aircraft applications. A number of GSE possibilities were discussed between Boeing and Sandia in March of 2008, with a decision made to focus on a piece of GSE that also had non-aviation uses in order to promote fuel cell use in a broader commercial market. Boeing noted that airline maintenance crews often used dieselpowered mobile lighting units to illuminate aircraft during ground service and maintenance operations, and thus would be a good candidate platform for replacing noisy, inefficient and polluting diesel technology with quiet, efficient and zero-emissions fuel cell technology. The mobile light platform was also attractive as it had a multitude of non-aviation uses such as in roadway construction, and other general-purpose security lighting applications. In addition, the power level of the mobile light platform was a modest $5 \mathrm{~kW}$, which would make hydrogen storage easier and the overall system more feasible at the time. For these reasons, the decision was made to focus on developing a $\mathrm{H}_{2} \mathrm{LT}$, the basic idea of which is shown in Figure 1. Sandia performed an initial design of the $\mathrm{H}_{2} \mathrm{LT}$ using high pressure (350 bar) storage of hydrogen, and a $5 \mathrm{~kW}$ PEM fuel cell.

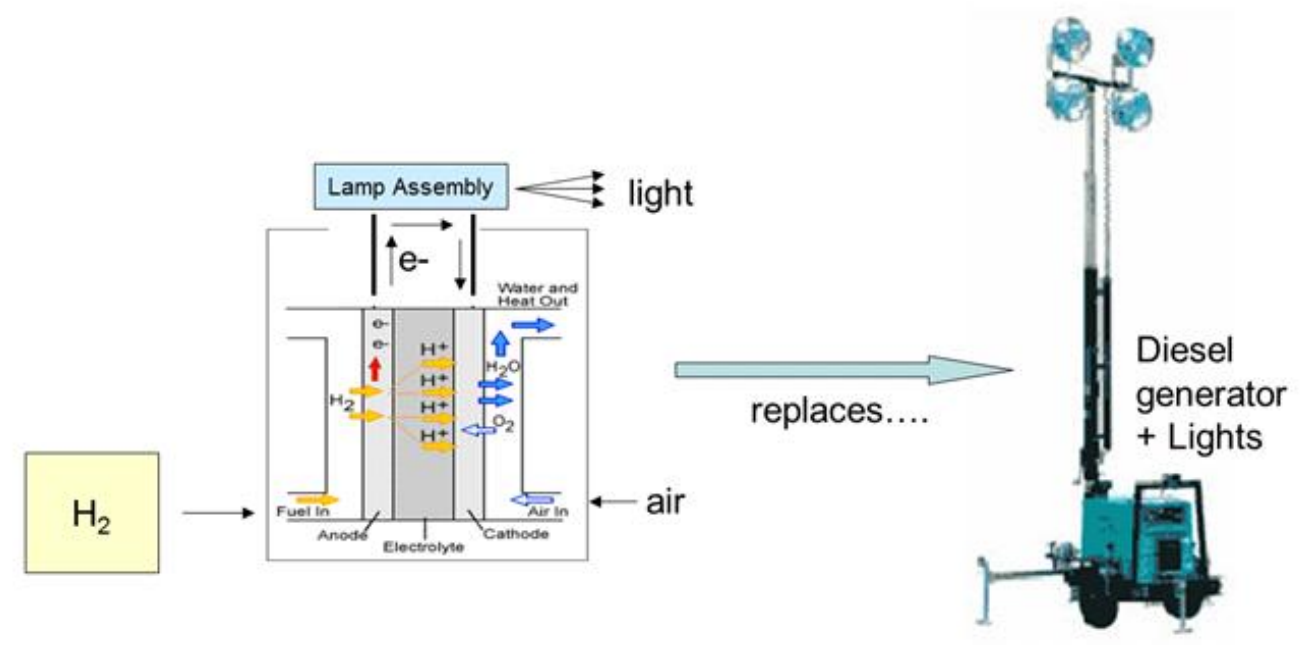

Figure 1: General concept of the $\mathrm{H}_{2} \mathrm{LT}$. The $\mathrm{H}_{2} \mathrm{LT}$ replaces a traditional diesel-powered light tower with a system that combines gaseous hydrogen (stored on the system), a PEM fuel cell, and an energy efficiency lighting (lamp) technology. 


\section{Assembling the Project Team:}

The overall team-building strategy was to bring together new technology holders, mass manufacturing capability, and end-users to enable mass production of a zero-emissions $\mathrm{H}_{2} \mathrm{LT}$ product whose design had prior input from end-users of the technology. The history of the team formation may be of interest to those contemplating similar hydrogen technology market transformation efforts.

Boeing and Sandia were the original project members, with Boeing providing the original seed funding. To seek further partners from the local hydrogen community, Klebanoff delivered a talk at the California Hydrogen Business Council on May 16, 2008. Two audience members expressed interest in the project: Bill Elrick from the California Fuel Cell Partnership (CaFCP) and Tom Damberger from Golden State Energy. Both the CaFCP and Golden State Energy became active project team members that evening.

Given the aviation origin of the project, it was desirable to have an airport involved as an enduser of the technology. Elrick, who had a prior experience in alternative fuel (natural gas) infrastructure development at airports, approached Roger Hooson, senior planner for the San Francisco International Airport (SFO), and Derek Fliess, equipment manager for SFO. SFO is a leader amongst U.S. airports in exploring new energy efficient and low-emissions technology, and joined the development team. The team needed an institutional partner who could mass manufacture PEM fuel cells. Damberger had an existing relationship with Altergy Systems, a mass manufacturer of robust $5 \mathrm{~kW}$ PEM fuel cells used primarily as backup telecom power, and the only manufacturer of PEM fuel cells with a robotic assembly system capable of mass production. Altergy joined the project as the fuel cell manufacturer. Damberger also reached out to Multiquip Inc. (MQ), a leading manufacturer of rental construction equipment, and a manufacturer of diesel-powered light towers. Torsten Erbel, Vice President for Product Development at Multiquip saw the zero-emissions fuel cell technology as a solution to the increasingly strict emissions restrictions being placed on diesel-based equipment. As a result, MQ joined the effort as the commercialization lead for the $\mathrm{H}_{2} \mathrm{LT}$. MQ would go on to create the first commercial construction technology platform based entirely on PEM fuel cells called Earthsmart ${ }^{\mathrm{TM}}$, for which the $\mathrm{H}_{2} \mathrm{LT}$ was the first product.

The project had two important connections with the California Department of Transportation (Caltrans). Tom Damberger knew Steve Prey, who was the Statewide Energy Program Coordinator for Caltrans, doing development work in the areas of $\mathrm{H}_{2}$ and LED technologies. Prey provided early guidance and encouragement in pursuing a collaboration with Caltrans. Independently, on October 29, 2008, Randy Iwasaki, the Director of the Caltrans, visited Sandia management for a meeting to discuss areas of mutual research interest. Klebanoff presented the emerging $\mathrm{H}_{2} \mathrm{LT}$ project, describing its potential for zero-emissions road construction use. Iwasaki directed the Caltrans Division of Research and Innovation (DRI) to engage in the project, with Randy Woolley from DRI being the Caltrans representative who would oversee 
field-testing with Caltrans as well as fund a study of the lighting options for the technology. Caltrans engaged one of their university research partners, the Advanced Highway Maintenance and Construction Technology Research Center out of U.C. Davis to coordinate Caltrans fieldtesting of the $\mathrm{H}_{2} \mathrm{LT}$, and perform testing of metal halide $(\mathrm{MH})$, plasma and LED lighting for the unit, which will be reported in detail elsewhere [4]. Caltrans and U.C. Davis became project partners in these capacities.

The project needed a mass manufacturer of lighting technology. With assistance from Mickey Oros of Altergy, Tom Damberger contacted Thomas Skradski of Lumenworks, a lighting technology and design outfit in Oakland CA. Lumenworks joined the project, and recommended an emerging energy-efficient lighting technology (circa 2009) called plasma lighting [5] that could operate on the DC voltage provided by the PEM fuel cell. Plasma lighting is manufactured by Luxim Corporation, and fabricated into lighting fixtures by Stray Light Optical Technologies. When the project goals and aims were described to these companies, they joined the development team as well.

Altergy Systems had been in prior communication with Paramount Pictures in Hollywood CA on the topic of fuel cell power technology, and discussions continued with the $\mathrm{H}_{2} \mathrm{LT}$. On January 14, 2010, an early $\mathrm{H}_{2} \mathrm{LT}$ prototype called the "Alpha System" was demonstrated inside Stage 17 of Paramount Pictures in Hollywood CA, at the invitation of Mark Bauserman, the Chief Engineer of Paramount at the time. The unit was demonstrated to representatives of Fox Studios, Universal Studios, Warner Brothers Studios and Paramount, amongst others and also to Saunders Electric Inc., the leading provider of diesel-based mobile power systems to the entertainment industry. Russell and Candace Saunders were impressed with the zero-emissions nature and how quiet the $\mathrm{H}_{2} \mathrm{LT}$ technology was. Saunders Electric joined the development team at that time, and used the prototype Alpha $\mathrm{H}_{2} \mathrm{LT}$ in their work at the 2010 Academy Awards on March 8, 2010. Prior to the 2010 Academy Awards, the project obtained funding support from the U.S. Department of Energy (DOE) Fuel Cell Technologies Office Market Transformation program, which allowed five additional near-commercial "Beta" units to be built with improved capabilities that could be field-tested in challenging environments.

With funding available from the DOE, the project team reached out to the NASA Kennedy Space Center (KSC) as an end-user of the $\mathrm{H}_{2} \mathrm{LT}$ technology with a deep knowledge of hydrogen systems, as liquid hydrogen was used to fuel the Space Shuttle Orbiter and also the Saturn V launch vehicle used in the Apollo and Skylab programs. The NASA KSC location in southern Florida made it a perfect site to test the corrosion resistance and performance of the unit in a hot, humid and salty marine environment. KSC did not join the project as an official partner, but was a close collaborator during the nearly two-year deployment of $\mathrm{H}_{2} \mathrm{LT}$ systems there. During the KSC field tests an $\mathrm{H}_{2} \mathrm{LT}$ was used to support operations for the last Space Shuttle launch (Atlantis, July 8, 2011). 
Although the initial $\mathrm{H}_{2} \mathrm{LT}$ design employed Type III, 350 bar carbon fiber overwrapped pressure vessels (COPV) (i.e., "composite tanks") as the chosen method of hydrogen storage, the project did consider the possibility that one day a metal-hydride tank could be used to store hydrogen for such an application. The project approached Ovonic Hydrogen Solutions, then a commercial source of interstitial metal hydride $\left(\mathrm{AB}_{2}\right)$ hydrogen storage systems. Boeing funded an analysis of the performance of such a tank for the $\mathrm{H}_{2} \mathrm{LT}$ [6]. Ovonic joined the effort, although the project never did build a system based on interstitial metal hydride hydrogen storage because high-pressure gas storage seemed adequate to the task.

Taken together, this assembly of institutions formed the project team, shown in Figure 2. These institutions came together with a shared philosophy that commercially available fuel cell equipment that works better than their diesel counterparts needs to be created and disseminated, starting the transformation of the aviation GSE and construction equipment markets with fuel cell technology.

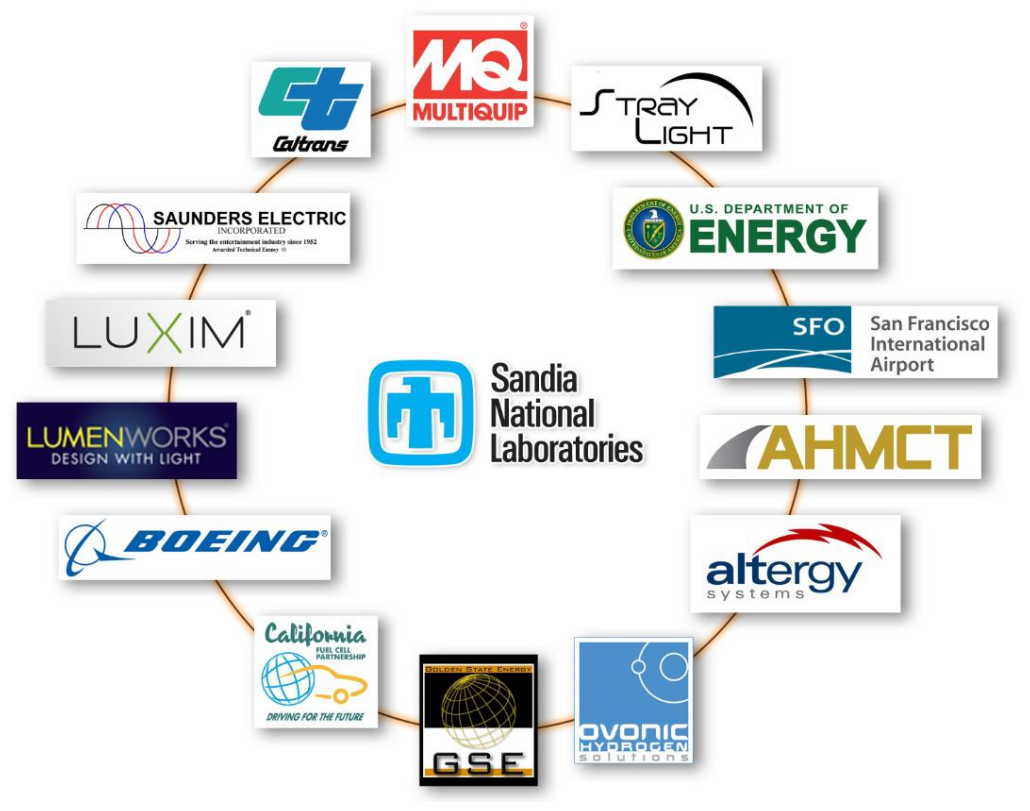

Figure 2: The $\mathrm{H}_{2} \mathrm{LT}$ Project Team (known informally as the Circle of Love). Entities providing additional assistance to the project included the NASA Kennedy Space Center, and Paramount Pictures (not shown).

The team-building strategy for the $\mathrm{H}_{2} \mathrm{LT}$ project can be summarized as follows. In order to design, build, field-test and commercialize this new piece of hydrogen fuel-cell-based equipment, we combined new technology holders (Sandia, Altergy, Ovonic) with mass manufacturing capability in fuel cells (Altergy), construction equipment (MQ) and lighting (Stray Light, Luxim, Lumenworks). To this group we added technically savvy and influential 
end-users (Caltrans, Saunders Electric, SFO) who could field-test prototypes of the technology in challenging environments and provide feedback on how the unit performed and ways to improve the system.

Having a U.S. national laboratory such as Sandia leading the development effort proved to be especially beneficial. In the U.S., national laboratories are forbidden by law from competing with industry, and are motivated by the broader national and DOE interest in lowering barriers to commercializing fuel cells in early markets. Sandia's not-for-profit posture in this regard helped create a sense of safety and trust within the project that the interactions with partners would be unbiased and fair. Sandia's established and broad capabilities in hydrogen technology (e.g. hydrogen storage, fuel cells and engineered fuel cell systems) and role as "honest technical broker" helped ensure the project had a sound technical footing and direction and that technical transfer to industry was prompt and complete. Sandia's prior work in the hydrogen "codes and standards" community lent additional credibility for the $\mathrm{H}_{2} \mathrm{LT}$ project in our briefings to emergency first responders, fire and safety professionals and law enforcement which were required for all of the field-tests.

Sandia adopted the management philosophy very early that the project would go in whatever direction the consensus of the group took it, without holding too tightly to the original concept of creating a piece of fuel-cell-based aviation GSE. This approach created a flexible and free environment in which collaborations flourished. Furthermore, management flexibility enabled the project to go in surprising and fruitful directions that ended up engaging a much larger and diverse community of end users and applications, better serving the fuel cell market transformation goals of the project. Boeing support for this management approach was invaluable.

The project was funded largely by in-kind contributions from the industrial partners. Boeing provided $\$ 150 \mathrm{~K}$ of seed funding. The U.S. DOE provided $\$ 650 \mathrm{~K}$ of project support for the construction of five additional $\mathrm{H}_{2} \mathrm{LT}$ units and their field testing. Caltrans provided $\$ 325 \mathrm{~K}$ in support of field testing by Caltrans staff and lighting characterization studies by the U.C. Davis AHMCT. The other in-kind contributions from the project partners totaled $\$ 1.22 \mathrm{M}$, giving a total project value of $\$ 2.35 \mathrm{M}$. Thus, the Boeing and DOE funding spurred considerable investment from the other partners, which was required for a successful project.

\section{Alpha $\mathbf{H}_{2} \mathbf{L T}$ Design:}

The $\mathrm{H}_{2} \mathrm{LT}$ system is conceptually composed of three subsystems: fuel cell, hydrogen storage and lighting. The PEM fuel cell used for all of the $\mathrm{H}_{2} \mathrm{LT}$ prototype units was the Altergy Systems FPS-5 (5 kW) PEM fuel cell, shown in Figure 3. This fuel cell was chosen because of its appropriate power output, rugged design, its successful use as a backup power system in 
hundreds of cell tower installations, and the fact that it could be mass manufactured by a robotic assembly line for use in the commercial $\mathrm{H}_{2} \mathrm{LT}$.

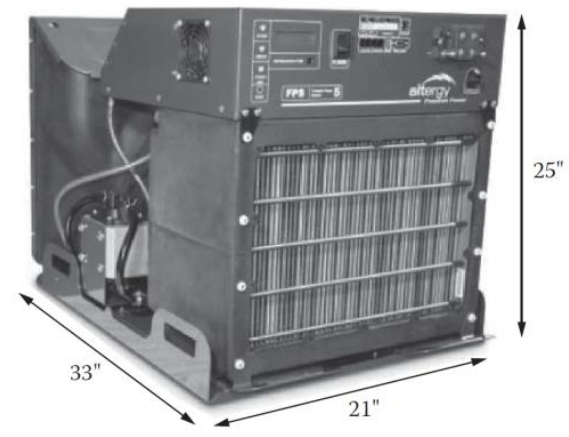

Figure 3: Altergy Systems FPS-5 PEM Fuel Cell used in all $\mathrm{H}_{2} \mathrm{LT}$ units for the project. The fuel cell has a maximal output power of $5 \mathrm{~kW}$.

The $\mathrm{H}_{2} \mathrm{LT}$ hydrogen storage system was comprised of Type III, aluminum-lined 350 bar COPV (e.g. "composite" tanks) with a capacity of $2.1 \mathrm{~kg}$ of hydrogen per tank. The tank chosen was the ALT 836U model from Structural Composites Industries (SCI). These tanks require a 350 bar source of hydrogen for filling. Our deployment sites were chosen to have access to highpressure hydrogen, as will be discussed later in the section discussing the $\mathrm{H}_{2} \mathrm{LT}$ field tests. We also considered using commercially available interstitial metal hydride hydrogen storage tanks available from Ovonic Hydrogen Systems. Such a tank was never used in a $\mathrm{H}_{2} \mathrm{LT}$ system because the high-pressure gas storage functioned adequately with sufficient volumetric storage density. A metal hydride tank would offer better volumetric storage density, and importantly, could be refueled using low-pressure sources of hydrogen (e.g. 150 bar hydrogen cylinders). The design of an $\mathrm{H}_{2} \mathrm{LT}$ system based on an Ovonic interstitial metal hydride hydrogen storage system was examined by Sandia, and will be described elsewhere [6].

The initial lighting used for the $\mathrm{H}_{2} \mathrm{LT}$ systems was plasma lighting which in 2009 was an emerging high-efficiency lighting technology already used for stationary applications (arena lighting, street lighting, etc.). Figure 4 gives a brief description of the plasma light technology, with a more complete description given elsewhere [5]. Plasma lights operate by directing RF energy via a waveguide into a plasma light bulb, which contains a proprietary mix of metal salts and gases. The RF energy excites the salt/gas mixture, giving off light. The suitability of the plasma technology for a mobile application such as the $\mathrm{H}_{2} \mathrm{LT}$ was not known at the beginning of the project, but there were some distinct advantages to plasma lighting such as a color rendering up to $96 \mathrm{CRI}$, a 50,000 hour bulb lifetime, an advertised high efficiency (lumens/watt) and compatibility with a DC voltage power source (i.e. the PEM fuel cell). 


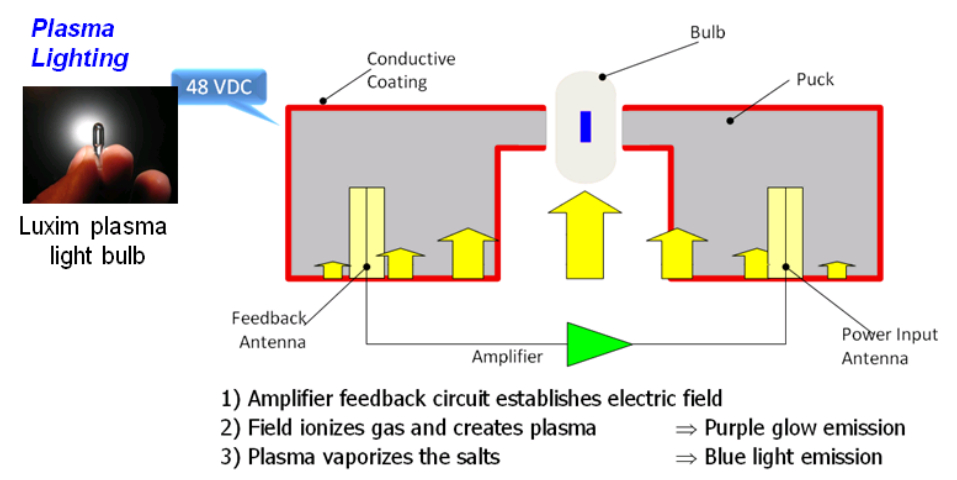

Figure 4: Schematic diagram of Luxim plasma light technology, with a photo of the plasma bulb shown.

The $\mathrm{H}_{2} \mathrm{LT}$ system design and construction began with the "Alpha Unit." The purpose of the Alpha $\mathrm{H}_{2} \mathrm{LT}$ was three-fold. First, we wanted to design and build a limited $\mathrm{H}_{2} \mathrm{LT}$ system (consistent with the Boeing seed funding) that would allow potential sponsors to see the unit and perhaps financially support its development. Second, the Alpha $\mathrm{H}_{2} \mathrm{LT}$ would enable initial feedback from end-users, accelerating the feedback/re-design development cycle. Third, we wanted to start the process sooner rather than later of MQ gaining familiarity with the technology, namely learning the techniques for constructing an integrated system involving hydrogen storage tanks, fuel cell, manifolding, and the enclosure accommodating the essential fuel cell systems, as well as the process of flushing the system with hydrogen and leak checking the finished and hydrogen-charged $\mathrm{H}_{2} \mathrm{LT}$.

Prior to the Fuel Cell Mobile Light project, MQ had no experience with hydrogen, fuel cells, or high pressure systems. The philosophy we adopted in the project would be that with the exception of the first Alpha $\mathrm{H}_{2} \mathrm{LT}$, every subsequent system would be constructed and tested entirely by MQ personnel, enabling MQ to develop the necessary expertise. This was a critical "tech transfer" aspect of the project, and an important goal of both Sandia and the DOE. To support this tech transfer, MQ staff travelled to Altergy to receive instruction in hydrogen and fuel cell system safety (conducted by Sandia, Altergy and the CaFCP), and in the leak-tight construction of manifolds made of 316 stainless steel rated for 350 bar hydrogen (conducted by Swagelok), as shown in Figure 5.

Alpha $\mathrm{H}_{2} \mathrm{LT}$ construction began with MQ shipping the base trailer to Altergy Systems. Altergy staff then installed the two ALT 836U hydrogen tanks and the $5 \mathrm{~kW}$ FPS-5 PEM fuel cell, as shown in Figure 6. Subsequently, the partially-assembled Alpha $\mathrm{H}_{2} \mathrm{LT}$ unit was shipped to MQ in Boise ID for integration of the lighting and mechanical systems onto the unit, installation of the electrical control panel, and final assembly and pressure certification. 


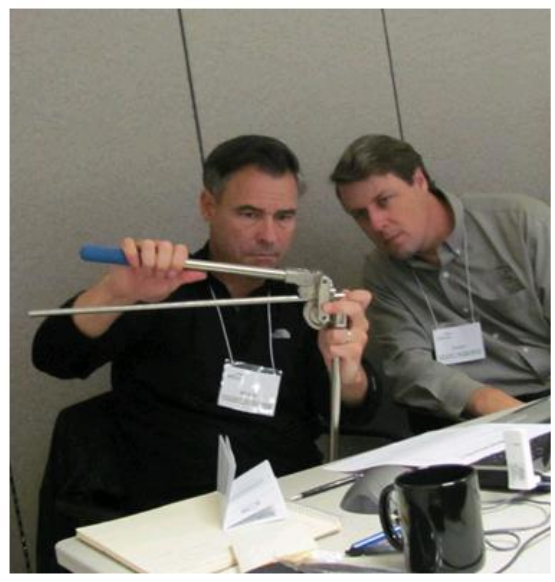

Figure 5: Bruce Coleman (left) and Jonathan Cuppett (right) of MQ learn the techniques for bending 316 stainless steel tubing for high-pressure $\mathrm{H}_{2} \mathrm{LT}$ hydrogen manifold construction.
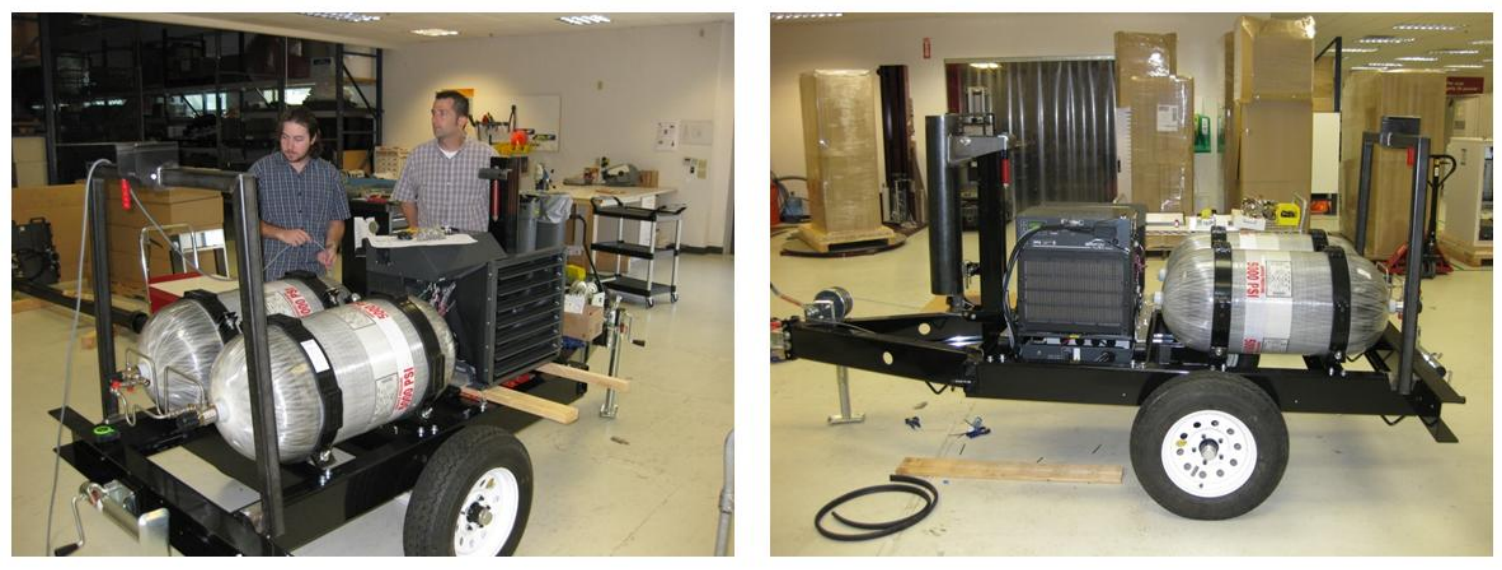

Figure 6: Build-up of the Alpha $\mathrm{H}_{2} \mathrm{LT}$ at Altergy Systems, September 4, 2009. Photos courtesy of Tom Damberger.

The completed Alpha system is shown in Figure 7. Within the white enclosure lies the two SCI ALT $836 \mathrm{U}$ hydrogen tanks storing $2.2 \mathrm{~kg}$ of hydrogen each at $350 \mathrm{bar}$ (4.4 $\mathrm{kg}$ total hydrogen storage) and the $5 \mathrm{~kW}$ Altergy Systems FPS-5 PEM fuel cell. The unit also has 8 plasma light bulbs located in 8 light fixtures located on a mast that can extend to 30 feet in height with full 
360 degree rotation. The lighting system draws $2.1 \mathrm{~kW}$ of power from the fuel cell. Since the lighting drew significantly less than the maximum fuel cell power, the unit was also outfitted with a $1.5 \mathrm{~kW}$ DC/AC inverter that could provide auxiliary $120 \mathrm{VAC}$ power to such items as power tools. The Alpha $\mathrm{H}_{2} \mathrm{LT}$ could provide full lighting for 30 hours, less if auxiliary power was also used while the lights were on.

Caltrans challenged the team to build the Alpha $\mathrm{H}_{2} \mathrm{LT}$ in time for display at the 2009 American Association of State Transportation Officials (AASHTO) meeting held in Palm Desert CA on October 23, 2009. The AASHTO meeting is an annual meeting of all the Departments of Transportation of the 50 U.S. states. Figure 8 shows deployment of the system at the 2009 AASHTO meeting. The left photograph shows that the $\mathrm{H}_{2} \mathrm{LT}$ illuminates a fairly large area, approximately $3 / 4$ of a football field. The unit was measured to have a noise rating of $42 \mathrm{~dB}$ at 23 feet, which is much quieter than the corresponding diesel light towers ( $73 \mathrm{~dB}$ at 23 feet), with no attempt having been made to sound condition the Alpha $\mathrm{H}_{2} \mathrm{LT}$ unit. The right photograph in Figure 8 shows the unit operating with several AASHTO attendees leaning on the unit, comfortably holding a conversation. The $\mathrm{H}_{2} \mathrm{LT}$ 's quiet operation was highlighted by many attendees as a particularly attractive aspect of the technology, although low-noise operation had not been a focus of the design effort.

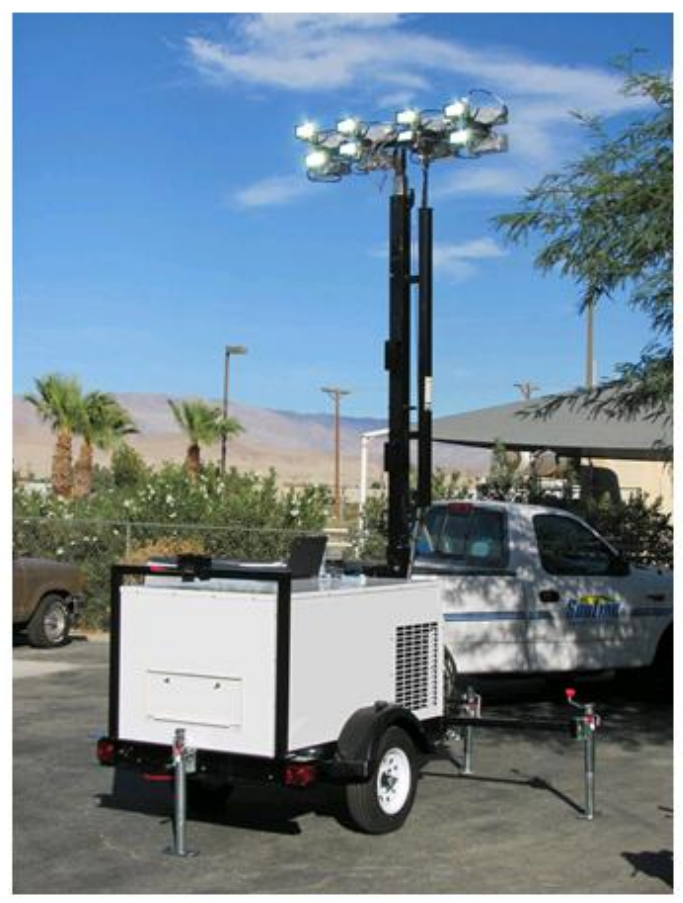

Figure 7: Alpha $\mathrm{H}_{2} \mathrm{LT}$ system, Palm Desert CA, October 18, 2009. 

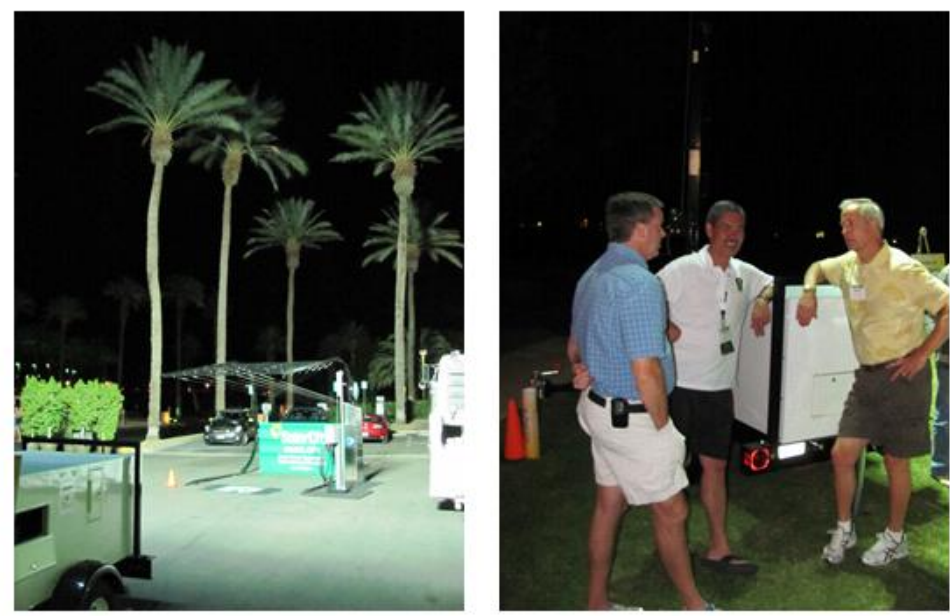

Figure 8: (L) Illuminated area of the Alpha $\mathrm{H}_{2} \mathrm{LT}$, with the Alpha $\mathrm{H}_{2} \mathrm{LT}$ in the foreground, lower left. (R): Caltrans Director Randy Iwasaki (white shirt) holds a conversation with AASHTO attendees next to the operating Alpha $\mathrm{H}_{2} \mathrm{LT}$ unit, indicating the low noise generated by the Alpha $\mathrm{H}_{2} \mathrm{LT}$.

In December of 2010, the project team (through Altergy Systems) contacted Paramount Pictures in Hollywood California. The Chief Engineer of Paramount at the time, Mark Bauserman, was interested in seeing the $\mathrm{H}_{2} \mathrm{LT}$ and arranged for a demonstration of the unit to lighting and power technology leads in the entertainment industry including Fox Studios, Universal Studios and Warner Brothers. A demonstration of the Alpha Unit was given on January 14, 2010 on Stage 17 at Paramount Pictures, as shown in Figure 9. Because the unit has zero emissions, it was allowed to be operated inside the soundstage. A crucial project contact with Saunders Electric took place during this demonstration. Saunders Electric is the leading provider of portable power to the entertainment industry, and provides diesel-based portable power to 58 award shows held annually in Los Angeles, including the Academy Awards (Oscars), the Screen Actors Guild (SAG) Awards and the Golden Globe Awards. Russ Saunders (see Figure 9 (R)) was impressed by the low noise and zero-emissions character of the $\mathrm{H}_{2} \mathrm{LT}$, and invited the project team to deploy the unit with Saunders operations at the 2010 Academy Awards held in Hollywood on March 8 of that year. This invitation commenced a 3-year period of field testing the $\mathrm{H}_{2} \mathrm{LT}$ technology in the entertainment industry by Saunders Electric. 

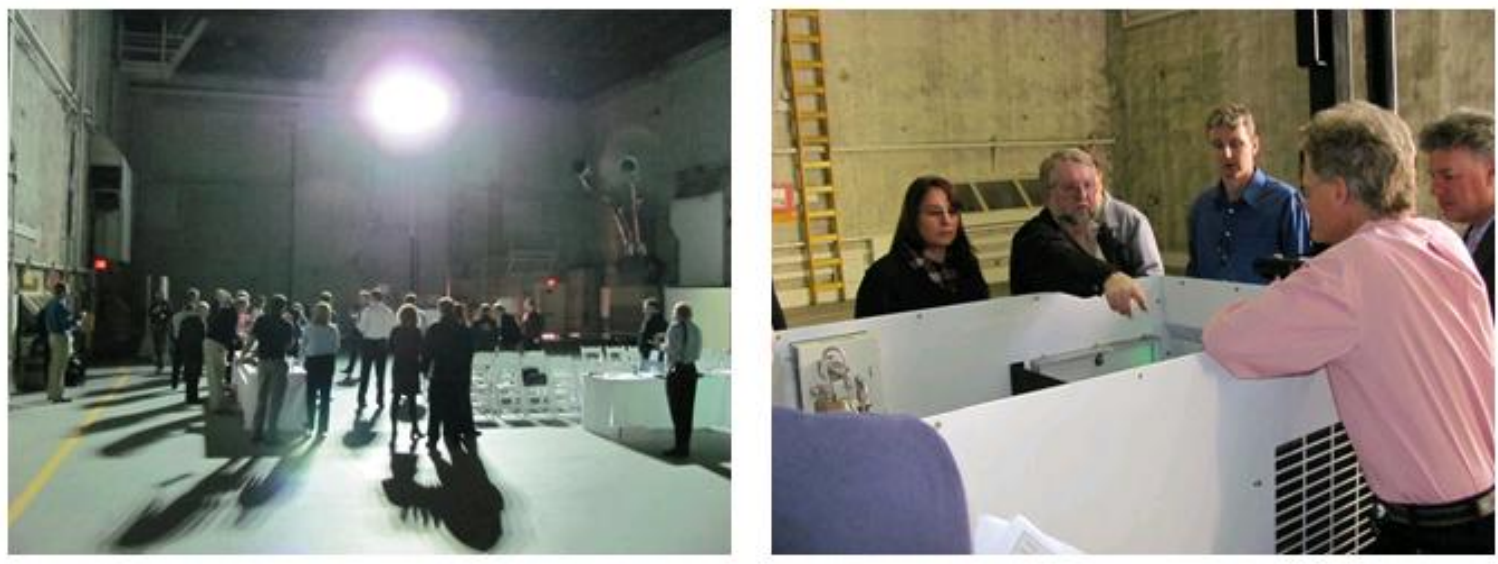

Figure 9: (L) Demonstration of the Alpha $\mathrm{H}_{2} \mathrm{LT}$ inside Stage 17 at Paramount Pictures on January 14, 2010 to representatives of nearby studios and companies interested in clean portable power; (R): Russ Saunders of Saunders Electric (pointing) discusses $\mathrm{H}_{2} \mathrm{LT}$ features with Mark Bauserman (pink shirt) of Paramount, while Chris Radley (blue shirt), Randy Woolley (Caltrans) and Candace Saunders look on. Note the lack of any sound conditioning in the steel enclosure of the unit.

Prior to use at the Academy Awards, the unit was demonstrated to members of the Los Angeles Fire Department (LAFD), and L.A. Building and Safety personnel. Approval from these departments had to be secured before use of the $\mathrm{H}_{2} \mathrm{LT}$ in such a high-profile and high-security semi-public event as the Academy Awards. Figure 10 shows Chris Radley from Altergy explaining some aspects of fuel cell properties to Eugene Andrews, the Fire Inspector for the Hollywood area, whose duties are to enforce the Municipal and State Fire codes as they pertain to public safety in all public assembly and special events (like the Oscars). This engagement with local fire and safety personnel was a continuing and vital component of the project activities wherever the unit was either displayed or used, and was an essential intrinsic component of the fuel cell market transformation process. 


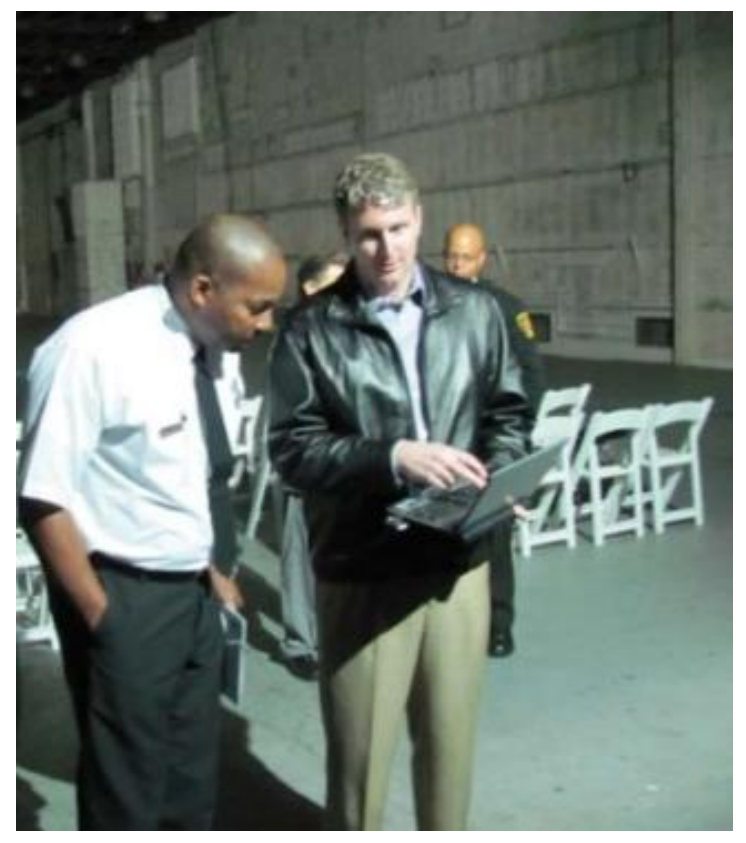

Figure 10: Chris Radley from Altergy discusses fuel cell technology with Chief Eugene Andrews of the LAFD.

During the week leading up to the 2010 Oscars, the Alpha $\mathrm{H}_{2} \mathrm{LT}$ was used by the Academy of Motion Picture Arts and Sciences (A.M.P.A.S.) construction crews to build up the famed Red Carpet on Hollywood Boulevard in front of the Dolby Theatre (formerly the Kodak Theater). Figure 11 shows the unit being used by the A.M.P.A.S construction crews both at night and during the cloudy rainy days leading up to the event. The crews used the unit with no supervision, and were the first to use the $\mathrm{H}_{2} \mathrm{LT}$ technology in real-world construction work. During the day of the Oscars event, the Alpha $\mathrm{H}_{2} \mathrm{LT}$ was used to provide security lighting at the International Press entrance to the Red Carpet, with the on-board $1.5 \mathrm{~kW}$ auxiliary power unit providing power to a security metal detector that press representatives had to pass through. Feedback was collected from the A.M.P.A.S. construction crews on the $\mathrm{H}_{2} \mathrm{LT}$ performance. After the awards ceremony, Russ Saunders presented a post-Oscars debrief attended by about 60 individuals comprised of vendors, producers, technicians, engineers, and Academy personnel. Saunders reported the debrief attendees were "quite excited at the $\mathrm{H}_{2} \mathrm{LT}$ developmental prospects and have instructed me to use these devices at my discretion on all events associated with the Academy's productions." 

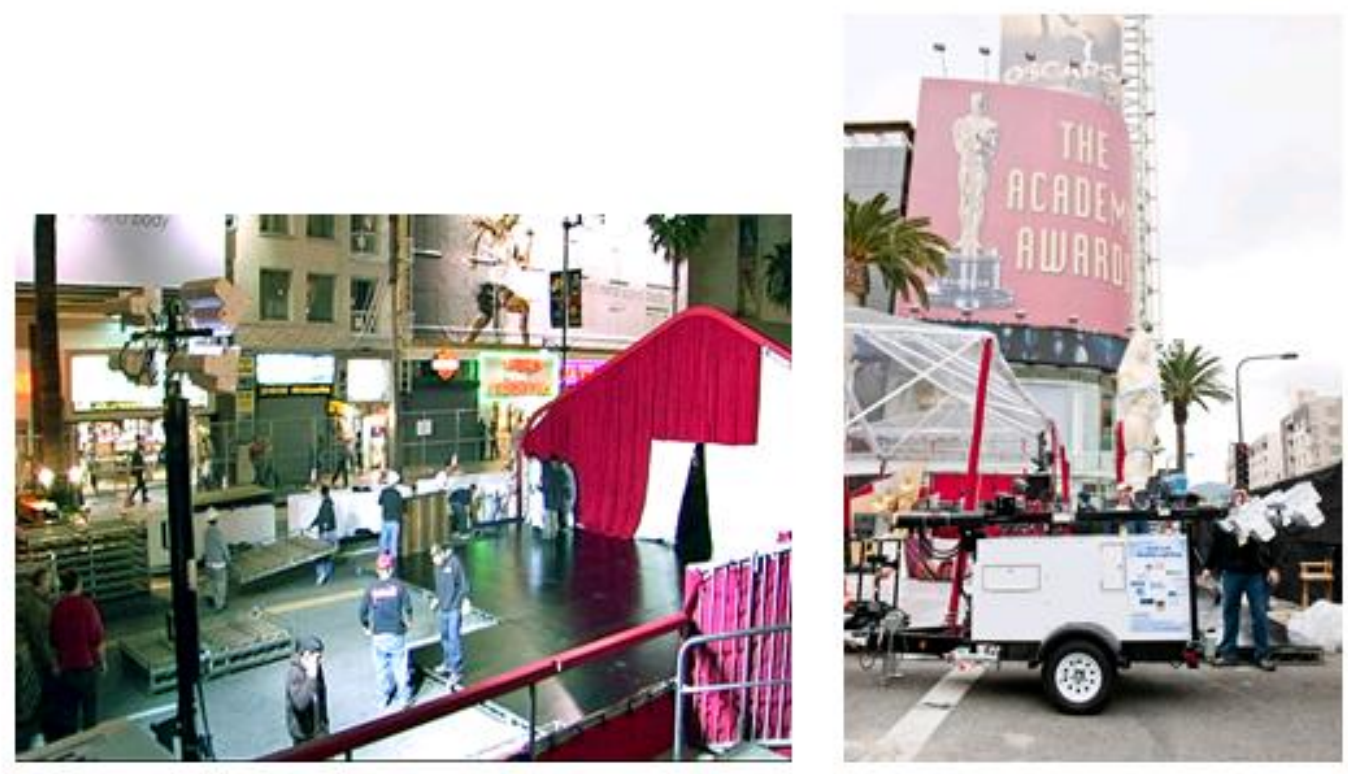

Figure 11: (L) Use of the Alpha $\mathrm{H}_{2}$ LT by A.M.P.A.S construction crews on March 5, 2010 in the build-up of the Red Carpet at the 2010 Academy Awards. The $\mathrm{H}_{2} \mathrm{LT}$ unit is in the lower left hand corner of the picture. Photo courtesy of Ron Roy Productions. (R) The $\mathrm{H}_{2} \mathrm{LT}$ by the Red Carpet on March 6, 2010. Photo courtesy of A.M.P.A.S.

Hydrogen fuel (at 350 bar) for the 2010 Oscars deployment was provided by an Air Products Mobile Hydrogen Station which was located at the Saunders Electric yard for the duration of the event (see Figure 12). Saunders staff were trained in the use of the self-contained Air Products Mobile Hydrogen Station by Air Products staff, and performed all refuelings themselves.
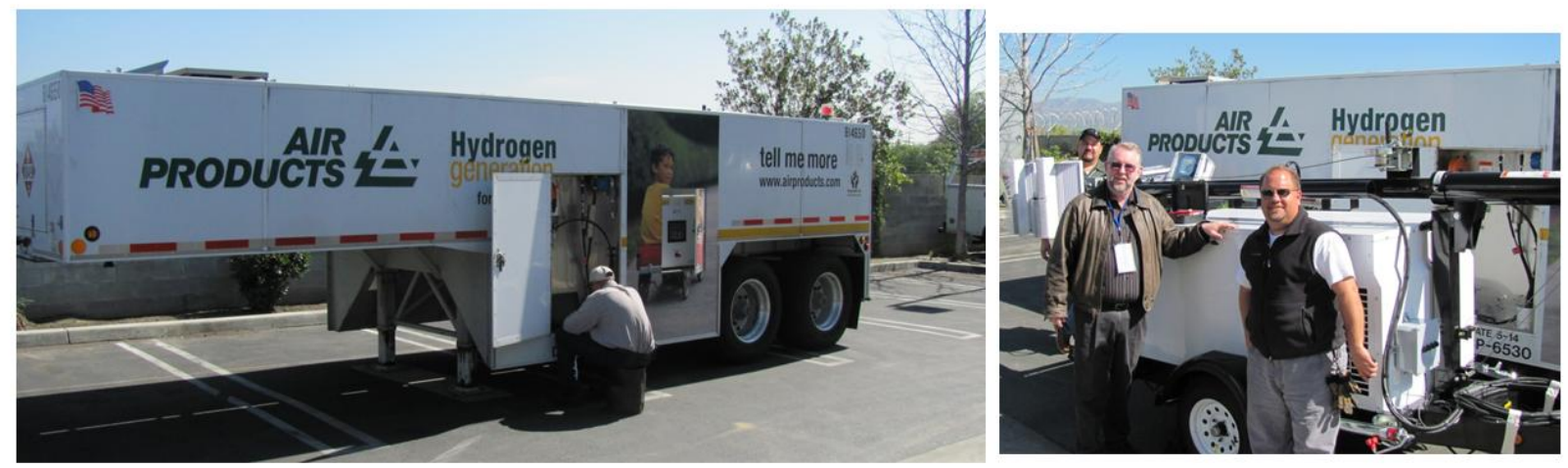

Figure 12: (L) Air Products Mobile Hydrogen Refueling Station used to support use of the Alpha $\mathrm{H}_{2}$ LT by Saunders Electric staff at the 2010 Academy Awards. (R) Saunders Electric staff involved in the $\mathrm{H}_{2} \mathrm{LT}$ use at the Oscars. Russ Saunders is standing on the left. 
With DOE funding, the project embarked on a significant expansion which allowed secondgeneration "Beta" units to be constructed and field tested in a variety of types of work in different climactic conditions.

\section{Beta $\mathrm{H}_{2}$ LT Design:}

The Beta $\mathrm{H}_{2} \mathrm{LT}$ system was designed to incorporate initial end-user feedback derived from the Alpha $\mathrm{H}_{2} \mathrm{LT}$, and to more closely resemble a real commercial piece of equipment. Steve Wingert of MQ performed the Beta design and assembly work. Figure 13 shows the Beta $\mathrm{H}_{2} \mathrm{LT}$ during the initial assembly. As was the case with the Alpha system, the trailer is constructed from heavy duty steel channel. For the Beta unit, four SCI ALT 836U 350-bar composite tanks were installed, giving a system total hydrogen storage of $8.4 \mathrm{~kg}$. This hydrogen storage capacity doubled that of the Alpha $\mathrm{H}_{2} \mathrm{LT}$, and increased the system run time (with plasma lights) to 60 hours. The hydrogen tanks are mounted with steel mounting brackets for firm seating, and are protected from impact threats by steel stabilizer bars. For additional safety the fuel cell is mounted to the back of the trailer, protected by a heavy duty impact channel.

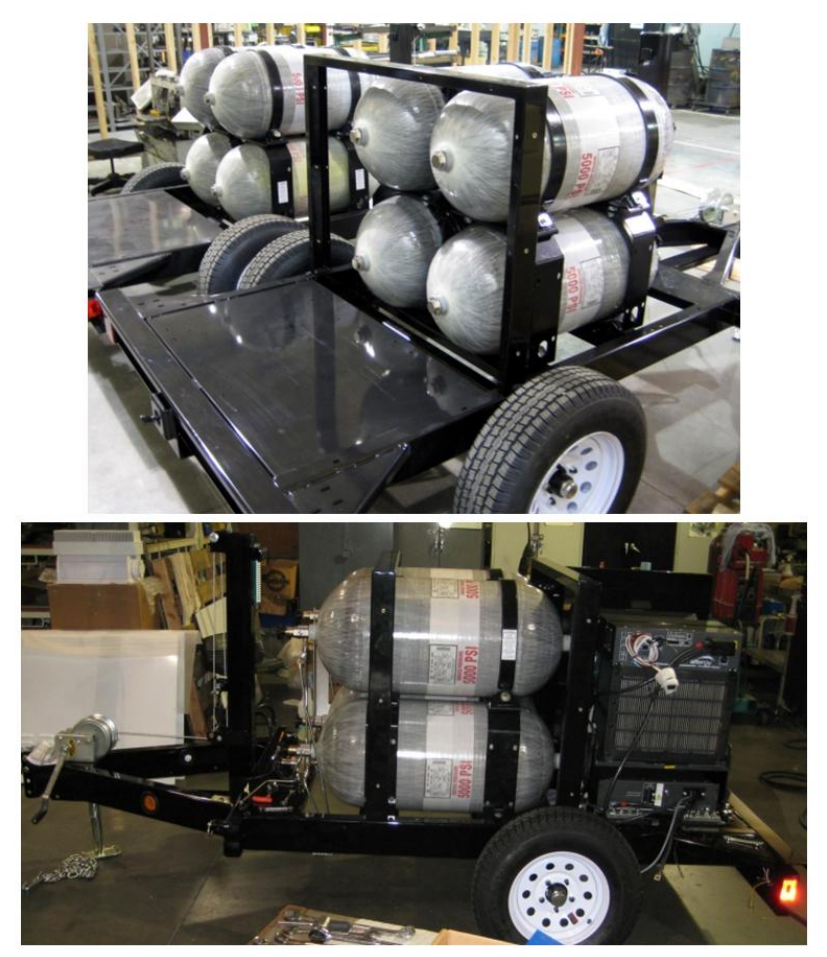

Figure 13: Initial assembly of a Beta $\mathrm{H}_{2} \mathrm{LT}$ unit: (Top) Mounting of four SCI ALT 836U composite hydrogen tanks on the Beta $\mathrm{H}_{2} \mathrm{LT}$; (Bottom) Mounting of both the $5 \mathrm{~kW}$ PEM fuel cell and hydrogen tanks. The "front" of the unit is to the left, toward the winch. Photos courtesy of Steve Wingert, MQ. 
The $\mathrm{H}_{2} \mathrm{LT}$ hydrogen manifold is constructed of 3/8" O.D. x 0.065 wall type 316 stainless tubing (ASTM 269) and Swagelok connection hardware rated for 442 bar (6500 psig) operation. Each composite tank has a temperature-actuated pressure relieve device (TPRD) and a multi-turn manual valve. The high hydrogen pressure of $<350$ bar is reduced to a much lower pressure of $<3$ bar at a regulator block before being directed to the PEM fuel cell. These features are shown in Figure 14. The manifold, connectors, valving, TPRD and pressure gauging have a temperature rating down to $-40^{\circ} \mathrm{F}\left(-40^{\circ} \mathrm{C}\right)$. The $\mathrm{H}_{2} \mathrm{LT}$ requires industrial grade $(99.95 \%$ pure) hydrogen for operation of the PEM fuel cell.

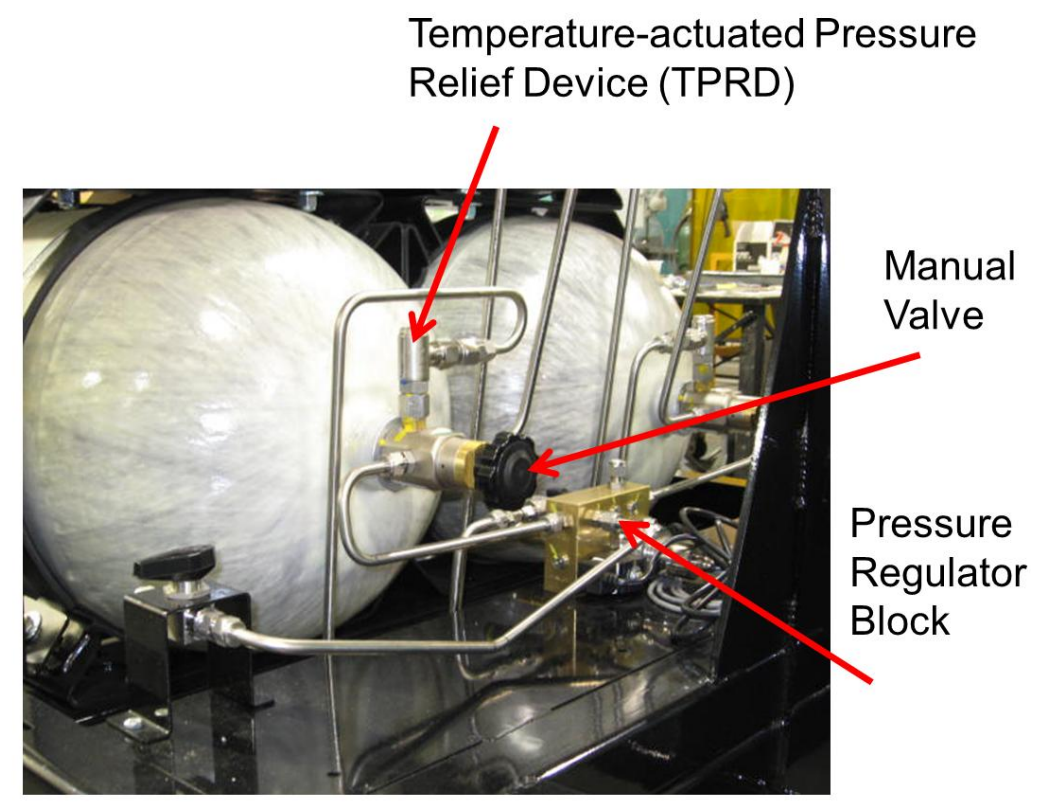

Figure 14: $\mathrm{H}_{2} \mathrm{LT}$ Manifold Design. Each composite tank has a TPRD and a multi-turn manual valve. The manifold is constructed of 3/8" O.D 0.065 " wall 316 stainless steel tubing and Swagelok connectors rated to 442 bar (6500 psig) hydrogen pressure. Photo courtesy of Steve Wingert, MQ.

In several of the Beta Units, a $1.5 \mathrm{~kW}$ DC-AC inverter (Samlex model SA 1500) was installed, to provide auxiliary 120VAC power to tools. The inverter was mounted on top of the PEM fuel cell, as shown in Figure 15. On units with AC power, the power is available near the electronics control panel via a 15A/120VAC GFIC panel outlet. 


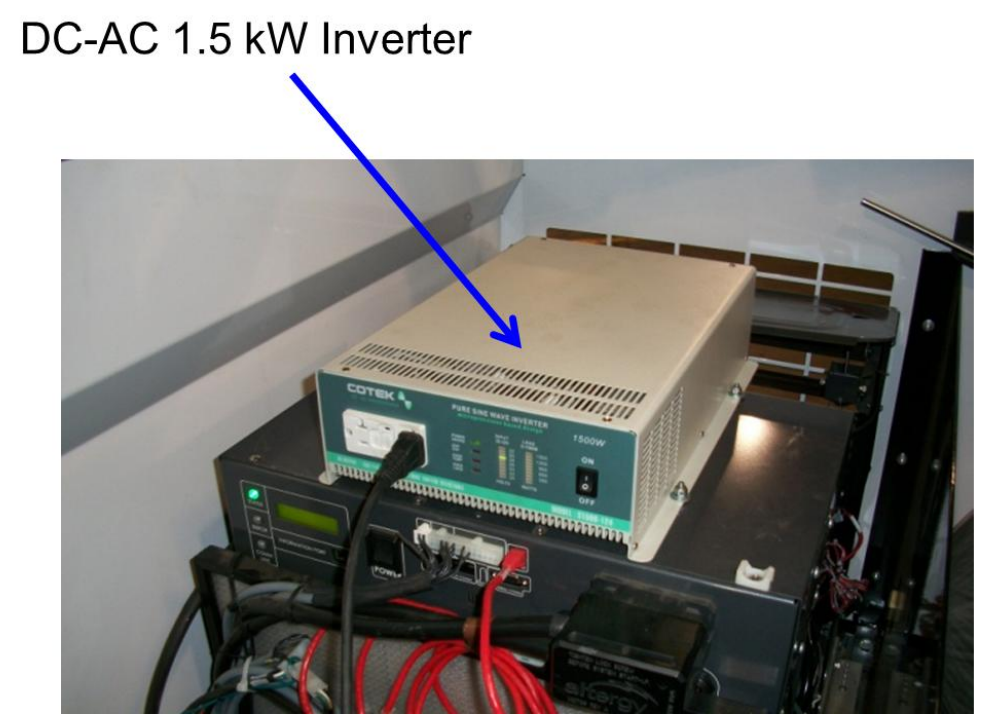

Figure 15: $1.5 \mathrm{~kW}$ 120VAC inverter (Samlex model SA1500) mounted on top of the PEM fuel cell in a Beta $\mathrm{H}_{2} \mathrm{LT}$. Photo courtesy of Steve Wingert, MQ.

The enclosure of the Beta $\mathrm{H}_{2} \mathrm{LT}$ was constructed of powder-coated and painted sheet metal, and was designed to accommodate the larger volume of the four composite hydrogen tanks and manifolding, full integration of the fuel cell, inverter (if present) and the electronic control system. The enclosure also provided an integrated fueling panel containing the fueling port, pressure gauge and manifold ball valve. The completed enclosure and details of the fueling port and electronics control panel are show in Figure 16.

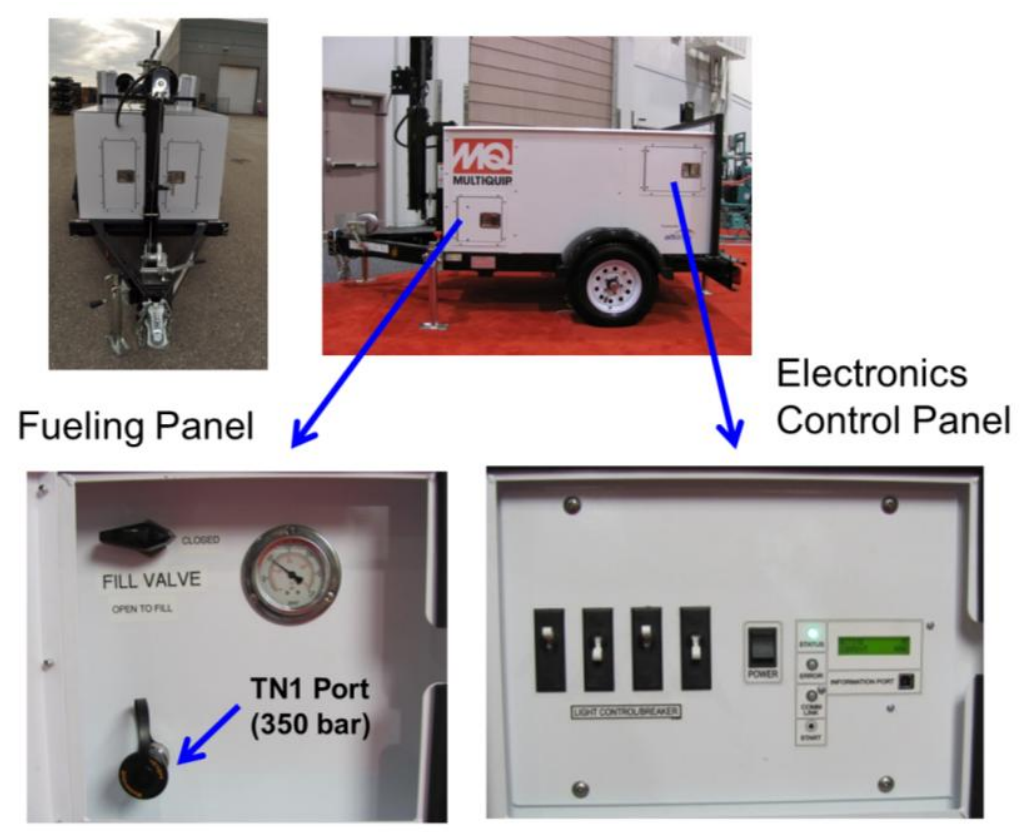

Figure 16: Beta $\mathrm{H}_{2} \mathrm{LT}$ Enclosure, with Fueling Panel and Electronics Control Panel 
The overall dimensions of the enclosure are 34.0 " tall $\mathrm{x} 46.0$ " wide $\mathrm{x} 71.4$ " long. The weight of the Beta $\mathrm{H}_{2} \mathrm{LT}$ unit is $\sim 2500 \mathrm{lbs}$. All fuel tanks, refueling and control panel access doors are lockable for safety and security for access by authorized users only. The $\mathrm{H}_{2} \mathrm{LT}$ unit can be towed behind a pick-up truck using standard hitch hardware (e.g. pintle or ball hitch).

Fueling is accomplished through an automotive style 350 bar TN1 connection port (WEH Products TN1 H2 (C1-31316-X1)) located on the fueling panel, with manifold pressure gauge and shut-off (fill) valve. The electronic control system allows one-button start-up of the fuel cell. Upon start-up, the PEM fuel cell undergoes a series of internal system checks, including a system leak check. After $\sim 1$ minute, power is available to the lighting system via 4 toggle light switches/circuit breakers. The Electronic Control panel provides a data information port to allow the PEM fuel cell system diagnostics to be accessed with a laptop computer. A green LED screen gives the status of fuel cell (active, undergoing leak test, in the process of shut-down, etc.). The PEM fuel cell possesses a hydrogen sensor, to that if hydrogen is detected within the enclosure, the fuel cell shuts down. Such a shut-down never occurred during the four years of field tests.

The lighting technology for the Beta units was either Plasma lights (as was used on the Alpha System), or LED lights from a couple of different manufacturers. The lighting technology will be discussed in more detail later.

After any $\mathrm{H}_{2} \mathrm{LT}$ unit (Alpha or Beta) was constructed at the MQ Boise Idaho manufacturing facility, the unit was transported to nearby Norco Inc., a leading gas supplier in the U.S.

Northwest. In collaboration with Norco staff, MQ staff pressurized the $\mathrm{H}_{2} \mathrm{LT}$ manifold and tanks to $5500 \mathrm{psig}$ with nitrogen and checked for leaks via bubble leak detection with soapy water. The required leak rate was no visible bubbles. After the 5500 psig nitrogen system leak check, the nitrogen charge was vented to $30 \mathrm{psig}$, and the system tanks and manifold were pumped out and then filled to $2800 \mathrm{psig}$ of hydrogen ( $99.995 \%$ pure). After the hydrogen charge, the entire system was leak checked again with combustible gas detector and bubble leak checked. The required leak rate at any line or fitting was no visible soap bubbles and no sign of detection on the combustible gas detector. The system was then charged to 5,000 psig of hydrogen and leak checked again with combustible gas detector and bubble-check.

We measured the overall leak rate of the $\mathrm{H}_{2} \mathrm{LT}$ manifold by valving off the hydrogen tanks, and observing the pressure decrease in the sealed-off manifold over time. Since the internal volume of the manifold is small $(\sim 150 \mathrm{~mL})$, a very small leak from such a small volume can be detected as a pressure drop by the system pressure gauge. In one such test, the hydrogen pressure in the manifold dropped from 5000 psig to 4000 psig over the course of 10 days, corresponding to a system leak rate of $0.9 \mathrm{Ncc} / \mathrm{min}$. The hydrogen community has established regulations [7] concerning acceptable leaks from hydrogen systems, and the maximal allowable loss from a hydrogen storage system is $150 \mathrm{Ncc} / \mathrm{min}$ for the stringent automotive application. The allowable hydrogen loss rate from any single leak is $3.6 \mathrm{Ncc} / \mathrm{min}$. Thus the $\mathrm{H}_{2} \mathrm{LT}$ manifolding is leak tight 
to a level exceeding the required standards. These hydrogen leak and permeation standards are conservative numbers based on laboratory tests of the minimum hydrogen leak rate that can be ignited by a flame held over the leak. A $3.6 \mathrm{Ncc} / \mathrm{min}$ hydrogen leak is considerably less than that which can be ignited. A review of hydrogen safety codes and standards including allowed hydrogen leak and permeation rates for fuel cell vehicle storage technology has been given by Sloane [7]. Field testing of the Beta units showed that this excellent pressure integrity was maintained throughout the field testing, which included towing $\mathrm{H}_{2} \mathrm{LT}$ units on all types of roads for in some cases several years.

One of the Beta $\mathrm{H}_{2} \mathrm{LT}$ units was outfitted with a "cold weather package" designed and installed by Altergy Systems. The concern was that if the $\mathrm{H}_{2} \mathrm{LT}$ was left turned-off in a very cold ( 25 ${ }^{\circ} \mathrm{F},-3.9^{\circ} \mathrm{C}$, ) environment, the fuel cell would have trouble starting if some of the internal gas channels became blocked with ice. This freezing would be in spite of the fact that unit performs a stack purge with hydrogen before final shut-down, removing residual water. For this cold weather Beta $\mathrm{H}_{2} \mathrm{LT}$ unit, the cold-weather package comprised of a heater and batteries were added to the system. The fuel cell software was modified such that when the fuel cell control system sensed the temperature was too cold, a pre-heat start up cycle would begin. During the 10 minute pre-heat cycle, the batteries operate the heater in the enclosure, allowing the fuel cell to warm up to a safe starting temperature before normal system start-up. Once operating, the waste heat from the fuel cell allows the unit to operate continuously down to $-40^{\circ} \mathrm{F}\left(-40^{\circ} \mathrm{C}\right)$. This cold weather package system was tested in an environmental cold chamber at Altergy Systems, and found to allow fuel cell start up at temperatures down to about $-20^{\circ} \mathrm{F}\left(-28.8^{\circ} \mathrm{C}\right)$.

\section{Characterizing the Lighting:}

The intrinsic energy efficiency of the lighting used on the Beta $\mathrm{H}_{2} \mathrm{LT}$ has a dramatic influence on the overall system performance. Lighting technology most suited for the 28 VDC output of the PEM fuel cell is plasma lighting (already discussed) and LED lighting. LED lighting in particular made dramatic improvements in efficiency (lumens per watt of input power) during the course of the project. The Caltrans DRI funded the U.C. Davis AHMCT to characterize the light output and illumination pattern on the ground for the $\mathrm{H}_{2} \mathrm{LT}$ using either plasma or LED lighting, and to compare the illumination output with a standard diesel-powered light tower using metal halide $(\mathrm{MH})$ lighting. Some results are shown in Figure 17. Both LED and plasma lighting have higher energy efficiencies than the standard MH lighting technology. However, on a per fixture basis, these newer technologies output less overall light. Thus, more "fixtures" are required to equal the output of a $\mathrm{MH}$ light/reflector assembly. For an $\mathrm{H}_{2} \mathrm{LT}$ outfitted with LED lights, substantially less fuel energy is required to produce the same light output as a diesel light tower with $\mathrm{MH}$ lights, due to the increased energy efficiency of both the LED lights and the PEM fuel cell. An in-depth discussion of the lighting tests will be given separately [4]. 


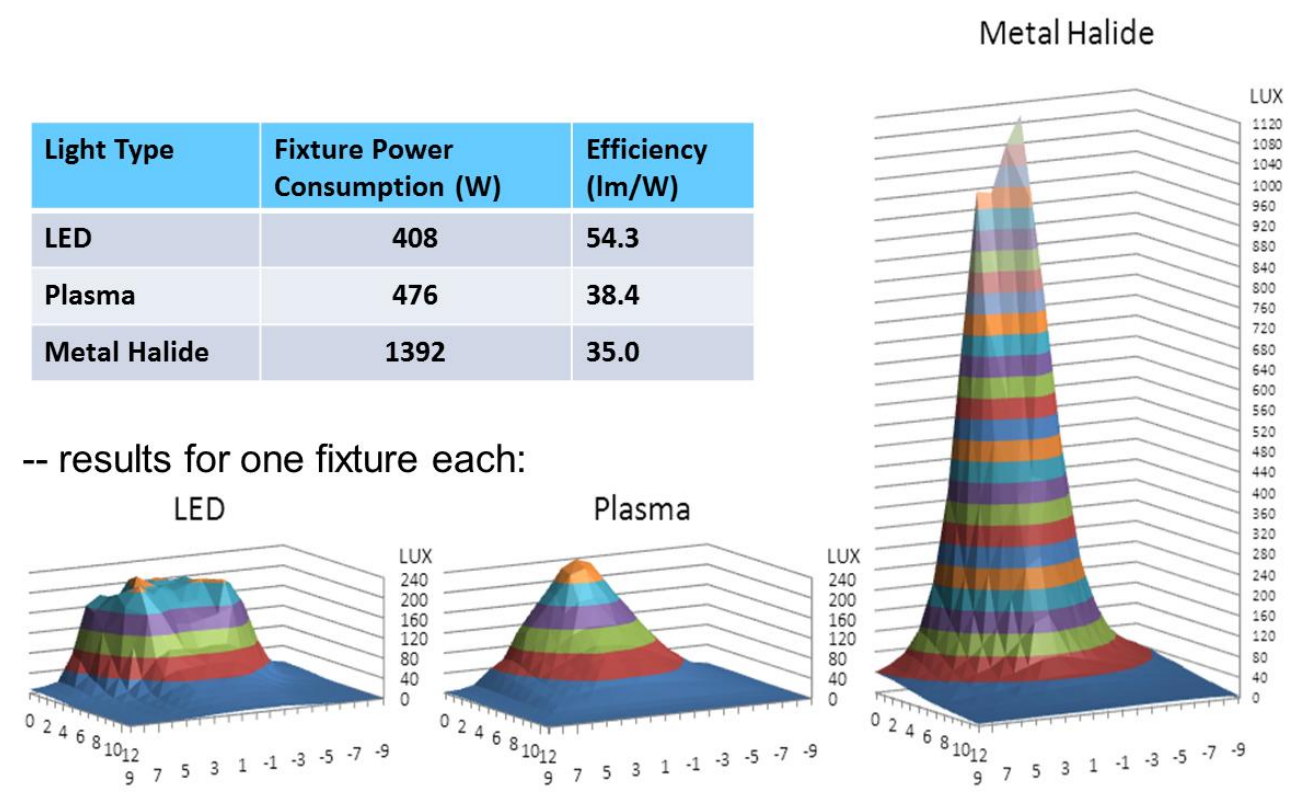

Horizontal Grid in Meters

Figure 17: Test results for illumination (measured LUX versus ground-plane $x-y$ location) pattern from LED, Plasma and Metal Halide Light fixtures. The LED "fixture" consists of an array of four individual Grote Trilliant 24V LED fixtures. The plasma and Metal Halide results are for single bulb fixtures of these technologies.

The observed difference between LED and MH lighting efficiency (lumens/watt) for any two systems can vary greatly due to differences between lighting manufacturers, but also due to the rapid decline in $\mathrm{MH}$ output with lifetime. At 10,000 hours, metal halide lights have lost $~ 50 \%$ of their original efficiency, whereas LED lighting can maintain $\sim 95 \%$ of their original output. So the actual difference observed in the field between light towers using the two different kinds of lights can vary dramatically. The results of Figure 17 were acquired on new LED fixtures and "used" MH lights with unknown history. We suspect that these results were for MH lights with 10,000 hours of service or more. 


\section{Comparing the Beta $\mathrm{H}_{2} \mathrm{LT}$ and a Diesel MQ LT-12D Light Tower:}

The environmental benefits of the $\mathrm{H}_{2} \mathrm{LT}$ technology relative to current diesel-fueled mobile lights have been calculated [8] by the U.S. DOE Fuel Cell Technologies Office (FCTO). The diesel unit used for the comparison is the Multiquip LT-12D light tower, shown in Figure 18.

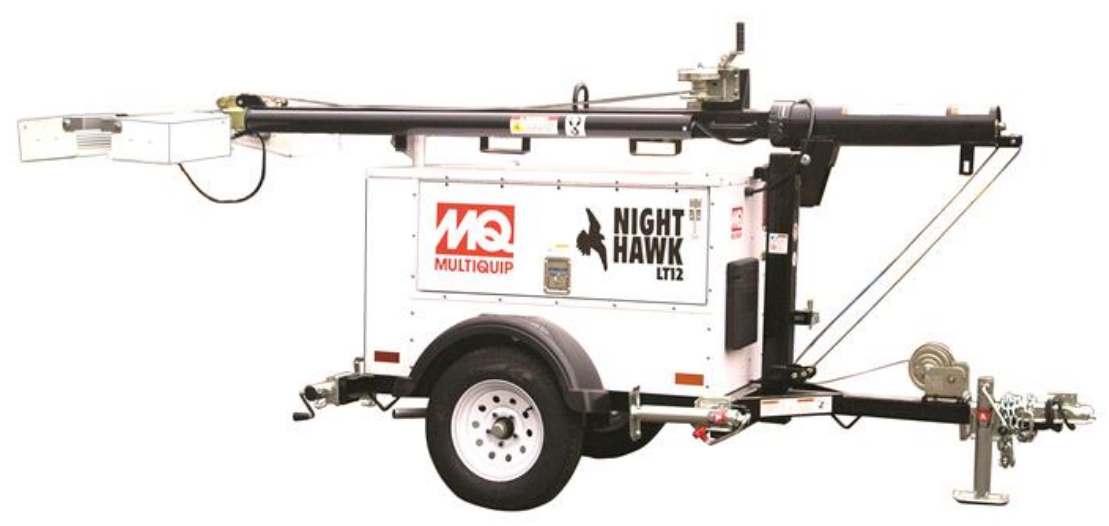

Figure 18: Multiquip diesel mobile light tower model LT-12D

There are many choices and manufacturers for LED lights, and they have varying energy efficiencies which determine $\mathrm{H}_{2} \mathrm{LT}$ duration and environmental performance. We will assume LED lighting comprised of Grote Trilliant 24V lamps, as characterized in Figure 17. A light tower can be configured based on the Grote Trilliant LEDs such that the total light output will be 177,600 lumens, consuming $3264 \mathrm{~W}$ of fuel cell input power. This light output would be about the same as a 4 lamp metal halide diesel light tower also characterized in Figure 17. This is a considerable light output; with 177,600 lumens output, one could read a book in otherwise pitch darkness at 150 yards distance from the $\mathrm{H}_{2} \mathrm{LT}$.

The results of the comparison are given in Table I. Both mobile light units are assumed to output 177,600 lumens, with Grote Trilliant LED lights used for the fuel cell systems and metal halide lights for the diesel-based LT-12D system [8]. 
Table I: Annual emissions and energy consumption savings associated with using one $\mathrm{H}_{2} \mathrm{LT}$ unit in comparison to using a diesel fueled LT-12D light tower.

\begin{tabular}{|l|l|l|}
\hline Annual $\mathrm{H}_{2} \mathrm{LT}$ Benefits (per unit) & Renewable $\mathrm{H}_{2}$ & NG-derived $\mathrm{H}_{2}$ \\
\hline Diesel Fuel Displaced per Year (gallons) & 970 & 970 \\
\hline $\mathrm{H}_{2}$ Consumed per Year (kg) & 375 & 375 \\
\hline $\mathrm{CO}_{2}$ (eq.) Savings per Year (kg) & 11,292 & 7,055 \\
\hline (NMHC + NOx) Savings per Year (kg) & 68 & 68 \\
\hline PM Savings per Year (kg) & 3.6 & 3.6 \\
\hline Fuel Energy Savings per Year, LHV (MJ) & 86,917 & 86,917 \\
\hline Total Energy Savings per Year, LHV (MJ) & 33,735 & 83,972 \\
\hline
\end{tabular}

Notes: NMHC stands for non-methane hydrocarbons; PM stands for particulate matter.

Renewable $\mathrm{H}_{2}$ is produced by wind-based electrolysis of water; NG-derived $\mathrm{H}_{2}$ is produced by steam reforming.

The benefits shown in Table I depend on how the hydrogen is manufactured, either via reforming of natural gas (NG), or by renewable (wind-based electrolysis) methods. These results assume a $\mathrm{H}_{2} \mathrm{LT}$ is used for 180 days a year for 10 hours a day. One $\mathrm{H}_{2} \mathrm{LT}$ unit fueled with renewable $\mathrm{H}_{2}$ reduces $\mathrm{CO}_{2}$ (eq) emissions by 11,292 kg per year, with concomitant savings in other criteria pollutants. Using an $\mathrm{H}_{2} \mathrm{LT}$ unit displaces 970 gallons of diesel fuel per year, and saves 83,972 MJ of total energy if the hydrogen is produced by steam-methane reforming of NG and 33,735 $\mathrm{MJ}$ if the hydrogen is produced by the renewable, but more energy-intensive, wind-based electrolysis of water.

One can compare the physical dimensions of the Beta $\mathrm{H}_{2} \mathrm{LT}$ and the current diesel light tower LT-12 D to reveal the differences in stored deliverable energy densities. These comparisons are shown in Table II. 
Table II: Comparison of Physical Parameters of the Beta $\mathrm{H}_{2} \mathrm{LT}$ and LT-12D mobile lights. The Beta $\mathrm{H}_{2} \mathrm{LT}$ stores $8.4 \mathrm{~kg}$ of hydrogen; the LT-12D stores 30 gallons of diesel fuel.

\begin{tabular}{|l|l|l|}
\hline Physical Attribute & Beta $\mathrm{H}_{2} \mathrm{LT}$ & LT-12D \\
\hline Enclosure Dimensions (“h” x “w” x "l”, inches) & 34 x 46 x 71.4 & 31 x 34 x 56 \\
\hline Enclosure Volume (L) & 1829 & 967 \\
\hline Light Tower Mass, fueled (kg) & 1132 & 786 \\
\hline Enclosure and Contents Mass (kg) & 467 & 385 \\
\hline Duration at 177,600 lumens output (hours) & 40.6 & 48 \\
\hline Engine Thermal Efficiency (\%) & 47 & 25 \\
\hline Engine Nameplate Power Output (kW) & 5 & 6 \\
\hline Stored Fuel Capacity (kg H2, or gallons diesel) & 8.4 & 30 \\
\hline Stored Fuel Energy, LHV (MJ) & 1005 & 4076 \\
\hline Noise Spec at 23 feet (dB) & 42 & 73 \\
\hline DSV Electrical Energy Density (MJ/L) & 0.258 & 1.053 \\
\hline DSG Electrical Energy Density (MJ/kg) & 1.01 & 2.65 \\
\hline Refueling Time (no external cooling water) & 10 mins & 4 mins \\
\hline
\end{tabular}

Notes: Nameplate Power Output is equivalent to maximum rated power output. DSV stands for Delivered System Volumetric; DSG stands for Delivered System Gravimetric.

In Table II, the mobile light enclosures contain the fuel storage $\left(\mathrm{H}_{2}\right.$ or diesel), engine (fuel cell, diesel generator) and all required manifolding, valving, pumps and other B.O.P items. These enclosures are quite compact in their design, with little wasted space, thereby allowing a realworld practical estimate of the system volumetric and gravimetric deliverable electrical energy storage densities for these technologies. None of these enclosures are sound conditioned. Thus, the dramatically quieter $(42 \mathrm{~dB}) \mathrm{H}_{2} \mathrm{LT}$ noise level reflects the intrinsically low-noise character of PEM fuel cells compared to diesel generators ( $73 \mathrm{~dB}$ ). We see from Table II that the $\mathrm{H}_{2} \mathrm{LT}$ possesses a smaller delivered system volumetric (DSV) electrical energy density of $0.258 \mathrm{MJ} / \mathrm{L}$ compared to that of the diesel-powered LT-12 D (1.053 MJ/L). For context, a typical 12-V leadacid battery has a volumetric stored energy density of $\sim 0.440 \mathrm{MJ} / \mathrm{L}[9]$. 
To estimate the real-world practical gravimetric $\mathrm{H}_{2} \mathrm{LT}$ and LT-12D deliverable electrical energy storage densities, we report the mass of the hardware within the enclosures, including the enclosures themselves in Table II. The $\mathrm{H}_{2} \mathrm{LT}$ has a delivered system gravimetric (DSG) electrical energy density of $1.01 \mathrm{MJ} / \mathrm{kg}$, whereas the DSG electrical energy density for the LT$12 \mathrm{D}$ is $2.65 \mathrm{MJ} / \mathrm{kg}$. To give these gravimetric energy density numbers a context, a typical leadacid battery has a stored gravimetric energy density of $\sim 0.190 \mathrm{MJ} / \mathrm{kg}[9]$.

\section{Field-Testing of the $\mathrm{H}_{2} \mathrm{LT}$}

All users engaged in field-testing a $\mathrm{H}_{2} \mathrm{LT}$ unit underwent in-person instruction on the $\mathrm{H}_{2} \mathrm{LT}$ technology and hydrogen safety by project staff including CaFCP, Altergy Systems, Multiquip and Sandia. In particular, end-users, their fire/safety personnel and in some cases first responders were instructed on all aspects of hydrogen properties and safety-related issues and procedures, as well as the PEM fuel cell technology used in the $\mathrm{H}_{2} \mathrm{LT}$. Any maintenance concerns arising from a $\mathrm{H}_{2} \mathrm{LT}$ unit were referred to Altergy Systems for initial evaluation, available on a 24-hour basis.

The field tests were conducted in a variety of locales chosen to challenge the technology environmentally and in terms of accomplishing a particular lighting task. The field tests were conducted from March 2010 until the project end on January 20, 2014. The field-test partners were:

1. Saunders Electric, who used the $\mathrm{H}_{2} \mathrm{LT}$ (both Alpha and Beta systems) for many award shows and television production work in the Los Angeles area.

2. The NASA KSC, who used the Alpha and Beta units for security lighting, and also to support special events such as the final launch of the Space Shuttle Atlantis on July 8, 2011. NASA KSC used the $\mathrm{H}_{2} \mathrm{LT}$ in the hot, humid marine air of coastal southern Florida, which represents a significant test of corrosion resistance.

3. Caltrans District 3, who used a Beta $\mathrm{H}_{2} \mathrm{LT}$ unit in the snow of the Sierra Mountains near Lake Tahoe CA and in Sacramento CA for a variety of road construction and repair activities, cleaning debris from hillsides, and for bridge and overpass inspection work.

4. SFO, who used a Beta $\mathrm{H}_{2} \mathrm{LT}$ for general area lighting, for lighting runway repair operations and a host of other maintenance procedures on the airfield.

5. The Connecticut Department of Transportation (ConnDOT), who used a Beta unit in support of the Q-Bridge construction project along I-95 in New Haven CT, the largest federally funded U.S highway construction project currently being conducted in the U.S.

The field testing of the unit in each of these venues will now be described.

\section{Entertainment Events, Los Angeles CA:}

Both the original Alpha Unit and a newer Beta $\mathrm{H}_{2} \mathrm{LT}$ unit were used by Saunders Electric from March 2010 to the present at a number of award shows in Los Angeles and also used to provide 
support for several television productions in the greater LA area. The units were used at the 2010, 2012 and 2013 Oscars, at the Screen Actors Guild (SAG) Awards in 2011, 2012 and 2013, and at the Golden Globe Awards in 2011, 2012 and 2013. For all of these shows, the units were used to illuminate construction work on the Red Carpet leading up to these events. As needed, the $\mathrm{H}_{2} \mathrm{LT}$ system provided illumination of the Red Carpet during the event itself. Figure 19 shows the $\mathrm{H}_{2} \mathrm{LT}$ providing illumination during construction of the Red Carpets at the 2011 Golden Globes, and at the 2012 SAG Awards. Introduction of the technology to the entertainment industry, through Saunders Electric and entertainment construction personnel, naturally leads to the development of the entertainment early market for this fuel cell mobile lighting technology.
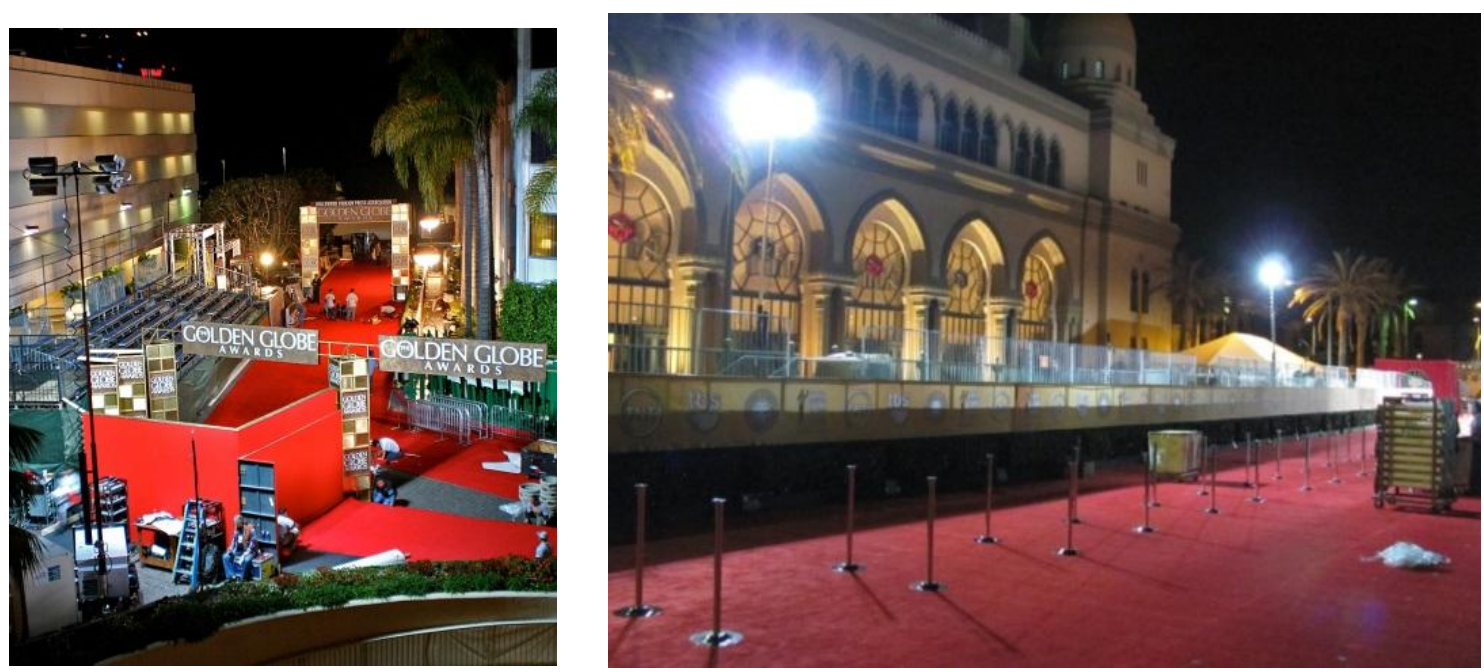

Figure 19: (L) Fuel Cell Mobile Light (lower left in picture) Illuminating the Red Carpet construction work at the 2011 Golden Globe Awards, The Beverly Hilton Hotel, Beverly Hills California, January 14, 2011. (R) Two fuel cell mobile lights deployed for Red Carpet construction at the 2012 Screen Actors Guild Awards, Los Angeles Shrine Exposition Center, Los Angeles California, January 29, 2012. The Golden Globes photo courtesy of Ron Roy Productions.

Figure 20 shows Ms. Jae Je Simmons, Executive Director of the New York Division of the Screen Actors Guild, who received an informal briefing of the PEM fuel cell technology using a stand-alone $10 \mathrm{~kW}$ Altergy Systems PEM power rack that was providing power for a security screening station at the 2012 SAG Awards. 


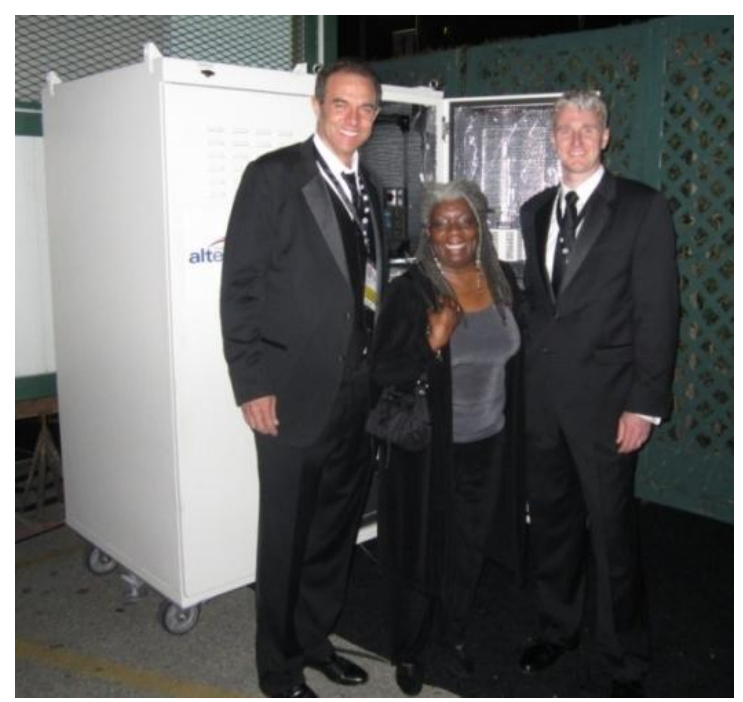

Figure 20: Ms. Jae Je Simmons, Executive Director of the New York Screen Actors Guild with project team members Klebanoff (left) and Radley (right) at the 2012 SAG Awards.

From 2011 on, 350 bar hydrogen for the two $\mathrm{H}_{2} \mathrm{LT}$ units undergoing entertainment field-tests was supplied free of charge by the Santa Monica Hydrogen Station. The longer duration of the Beta system ( 60 hours) proved essential at these events since the $\mathrm{H}_{2} \mathrm{LT}$ typically became "buried" in place in tight confines, surrounded by other equipment, and could not be removed for refueling.

\section{NASA Kennedy Space Center, Cape Canaveral FL:}

Deployment of initially the Alpha $\mathrm{H}_{2} \mathrm{LT}$ (on loan from Saunders Electric), followed by a Beta $\mathrm{H}_{2}$ LT system began at the NASA KSC in May of 2011, and extended until September of 2012. Since Space Shuttle Operations use an enormous amount of hydrogen (mostly stored as $\mathrm{LH}_{2}$ ), there was ample supply of hydrogen for this field test. The summer weather in Cape Canaveral Florida is characterized by high heat (average monthly high temperatures $\sim 90{ }^{\circ} \mathrm{F}, 32.2{ }^{\circ} \mathrm{C}$ ), very high humidity $(\sim 80 \%)$ and occasional torrential rains. Furthermore, the coastal location provides a salty marine air environment. Thus, the deployment at KSC was an excellent test of the durability of the system in strong weather, and the general corrosion resistance of the system.

As shown in Figure 21, the Alpha $\mathrm{H}_{2} \mathrm{LT}$ system was introduced to KSC personnel on April 21, 2011. There was no need for a hydrogen safety briefing, as NASA KSC originated many of the best practices for storing and handling hydrogen, both as a gas and a liquid. Prior to use at the KSC, the $\mathrm{H}_{2} \mathrm{LT}$ passed a thorough safety review by KSC safety subject matter experts. 

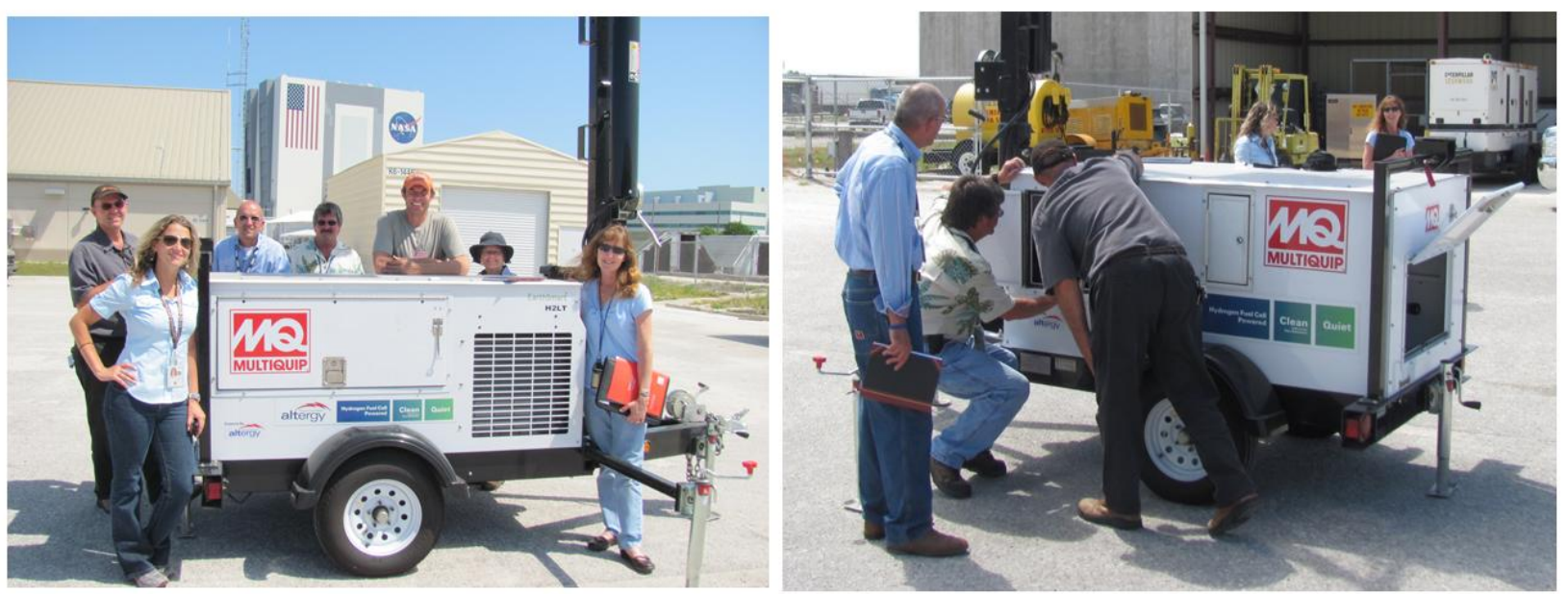

Figure 21: KSC equipment, propellants and safety personnel briefed about the Alpha $\mathrm{H}_{2} \mathrm{LT}$ operation. The Alpha $\mathrm{H}_{2} \mathrm{LT}$ was used at the KSC until August 2011; thereafter a Beta $\mathrm{H}_{2} \mathrm{LT}$ system was field-tested.

The systems were refueled to 350 bar using hydrogen available on-site, as shown in Figure 22.

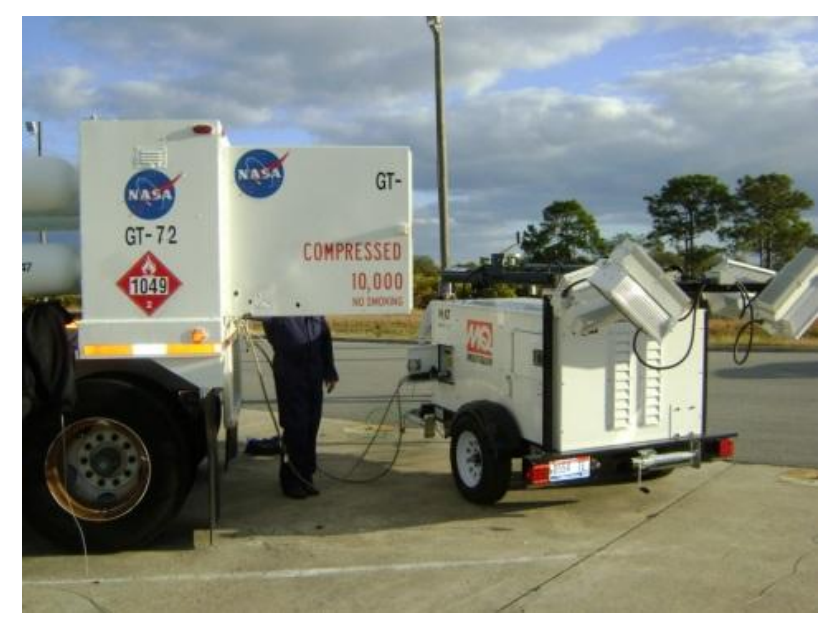

Figure 22: Beta $\mathrm{H}_{2} \mathrm{LT}$ system being refueled at the NASA KSC. Compressed gas is being provided at 350 bar. Photo courtesy of Rusty McGlaughlin, NASA KSC.

On occasion, the $\mathrm{H}_{2} \mathrm{LT}$ was used for special events, one of which was the final launch of a Space Shuttle (Atlantis), shown in Figure 23. The Alpha $\mathrm{H}_{2} \mathrm{LT}$ was used in the support of the International Press area operations, providing lighting at night. In addition, the DC-AC inverter on the unit allowed some auxiliary power functions, such as recharging camera batteries for several of the 1500 members of the international press corps in attendance. BBC radio conducted an interview with the project team about the fuel cell mobile light project. 


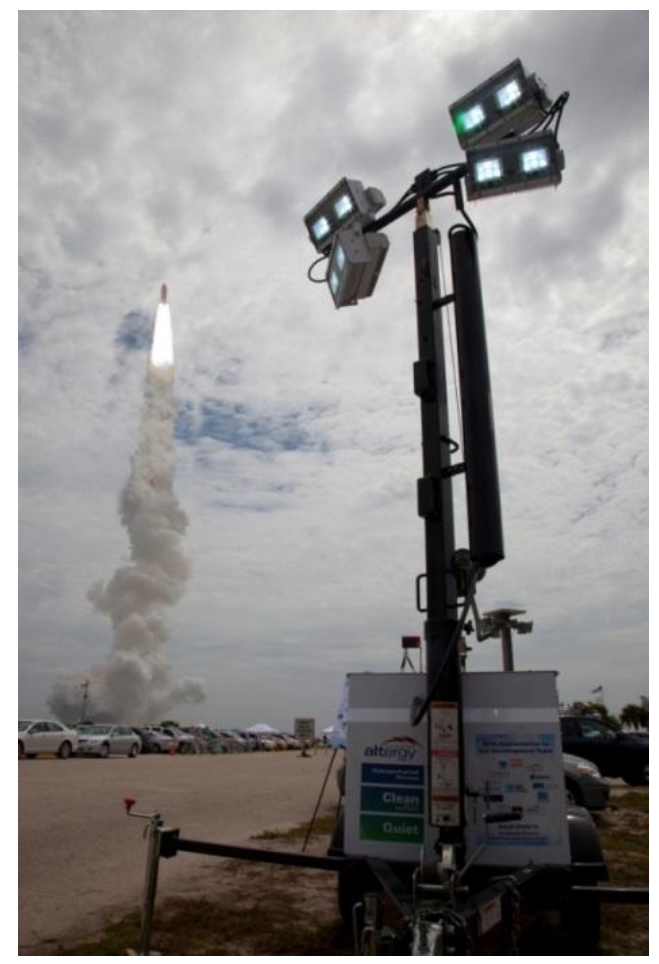

Figure 23: Alpha Fuel Cell Mobile Light $\left(\mathrm{H}_{2} \mathrm{LT}\right)$ in support of the last Space Shuttle launch (Atlantis), Kennedy Space Center, July 8, 2011. Photo courtesy of Steffan Schulz.

A month after the final Space Shuttle launch, the Alpha $\mathrm{H}_{2} \mathrm{LT}$ unit was returned to Saunders Electric, and a year-long field test of the Beta $\mathrm{H}_{2} \mathrm{LT}$ commenced at the KSC. The unit was used to provide security lighting for a new building on the site. After one year field-test, the unit was inspected on September 11, 2012 at the Institutional Support Contract (ISC) Generator Shop by two corrosion experts at NASA. A report of the corrosion findings and recommendations for how the system could be improved for corrosion resistance was forwarded to MQ so that the learning could be folded into the ultimate commercial design. In general, the corrosion experts reported that the unit looked good despite being exposed to outdoor conditions at KSC for 1 year. The $\mathrm{H}_{2} \mathrm{LT}$ showed comparable signs of corrosion to similar types of ground support equipment that have been exposed for the same period. Most of the corrosion was in nonhydrogen parts of the system, for example the mechanical winch systems suffered corrosion, as did some cut corners in the $\mathrm{H}_{2} \mathrm{LT}$ enclosure. However, the high-pressure hydrogen manifold (composed of 316 stainless steel) showed only superficial and spotty discoloration. Both the Alpha and Beta $\mathrm{H}_{2} \mathrm{LT}$ performed without failure during the field tests at the KSC.

\section{Caltrans District 3, Sacramento CA:}

With coordination provided by Caltrans DRI and U.C. Davis AHMCT, a Beta $\mathrm{H}_{2} \mathrm{LT}$ system was deployed with the road crews of Caltrans District 3 which encompasses Sacramento California 
and the nearby Sierra mountains including Lake Tahoe CA. The unit was introduced on February 18, 2012 to the Caltrans District 3 Kingvale California yard located 20 miles west of Truckee California, as shown in Figure 24. The field-testing was managed locally by Wil White of U.C. Davis. Refueling of the unit was performed at the hydrogen station operated by the CaFCP in West Sacramento, 95 miles from Kingvale. As a result, in the course of the deployment and for refuelings, the unit was towed up and down rough mountain roads over 1100 miles without a single occurrence of a system hydrogen leak. This was a strong test of the physical durability and stability of the hydrogen systems (fuel cell, tankeage, manifolding), as there is very little suspension on the $\mathrm{H}_{2} \mathrm{LT}$ to cushion the ride as it was being towed. To our knowledge, fuel cells have never been exposed to the shock and vibration that occurred in the field-test with Caltrans. The fuel cell and hydrogen storage system and manifolding performed without failure, indicating the hydrogen systems and PEM fuel cell are sufficiently durable for the construction equipment application. The deployment was also a test of the endurance of the unit in cold weather. During the day, the unit was stored in a shed that had one side exposed to the elements, with no heating in the shed. At night, the unit was operated in sub-freezing temperatures. This particular $\mathrm{H}_{2} \mathrm{LT}$ system was outfitted with the "cold weather" package described previously to allow a delayed system start if the temperature should ever reach below $25^{\circ} \mathrm{F}\left(-3.9^{\circ} \mathrm{C}\right)$. Figure 24 shows the arrival of the $\mathrm{H}_{2} \mathrm{LT}$ at Caltrans District 3 and its storage and use in winter weather.

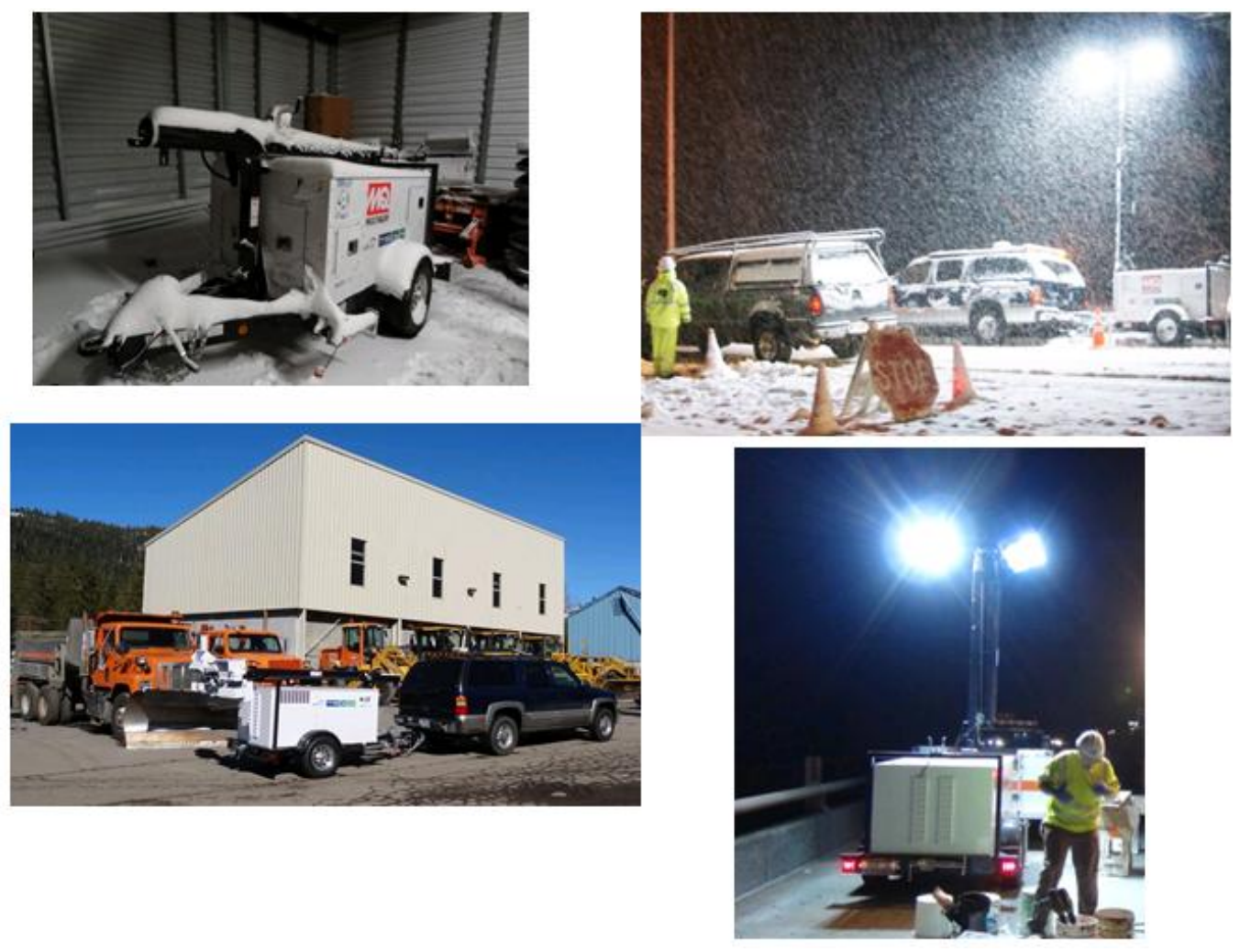


Figure 24: Clockwise from lower left: Delivery of the Beta $\mathrm{H}_{2} \mathrm{LT}$ to the Caltrans Kingvale, CA Yard on February 18, 2012; Storage of the $\mathrm{H}_{2} \mathrm{LT}$ exposed to winter conditions; $\mathrm{H}_{2} \mathrm{LT}$ illuminating a Caltrans chain control checkpoint along Interstate $80 \mathrm{~W}$ in the snowy Sierra, March 16, 2012; Use of the $\mathrm{H}_{2} \mathrm{LT}$ to perform bridge repair along Interstate $5 \mathrm{~N}$ in downtown Sacramento CA, September 20, 2012. Upper right photo courtesy of Tom Damberger, Golden State Energy. Upper left and lower right photos courtesy of Wil White, U.C. Davis.

In September of 2012, the unit was used to perform bridge repair along Interstate $5 \mathrm{~N}$ in downtown Sacramento CA (Fig. 24, bottom right picture). The Caltrans crews used the $\mathrm{H}_{2} \mathrm{LT}$ to repair concrete spalls at the edge of the bridge expansion joints-- a task needing a lot of illumination. The crews also used the unit for bridge inspection work where the unit illuminated bridge structures underneath the road surface.

\section{$\underline{\text { The San Francisco International Airport (SFO): }}$}

The $\mathrm{H}_{2} \mathrm{LT}$ technology was field tested at SFO beginning in February 2013. SFO has been a national leader in exploring ways of reducing GHG emissions at airports. Deployment at SFO offered a way to evaluate the system for durability in a cold, wet and foggy marine environment and assess the use of the $\mathrm{H}_{2} \mathrm{LT}$ in numerous aviation GSE applications such as aircraft maintenance, repair of land-based and water-based fire-fighting equipment, airfield plumbing repair, runway repair and general security lighting. As the $\mathrm{H}_{2}$ LT project began in March of 2008 with the $\mathrm{H}_{2} \mathrm{LT}$ conceived by Boeing as a piece of aviation GSE, the deployment at SFO represents the closing of a conceptual circle for the project. At one time, SFO had considered building a hydrogen station just off the airfield to provide hydrogen for a future fleet of airport fuel cell vehicles. However, plans for that station were cancelled, although SFO maintains a strong interest in hydrogen fuel cell technology.

A Beta $\mathrm{H}_{2}$ LT system outfitted with Grote Trilliant LED lights provided by Stray Light Optical Technologies was introduced to the SFO Equipment and Fire \& Safety Staff on February 27, 2013, as shown in Figure 25. SFO Fire and Safety staff fully approved use of the $\mathrm{H}_{2} \mathrm{LT}$ for airport and airfield operations. 


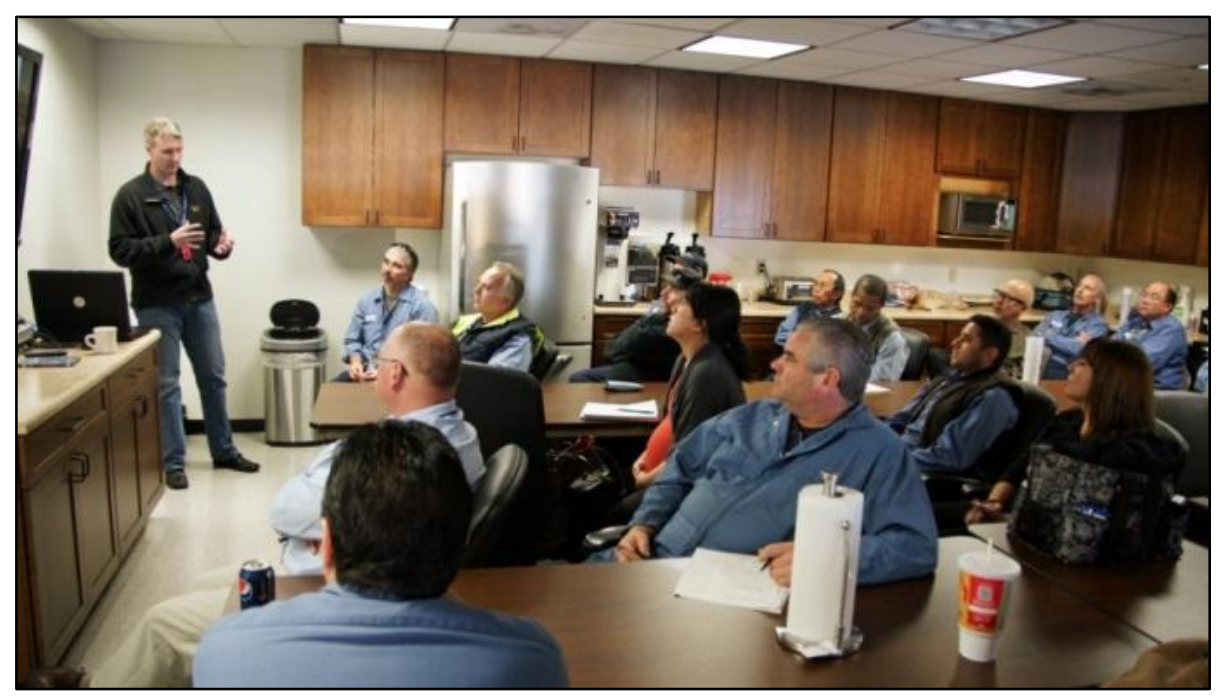

Figure 25: (L) Chris Radley explains $\mathrm{H}_{2}$ physical properties to SFO Fire and Safety Staff as well as Equipment Staff, February 27, 2013.

The first SFO $\mathrm{H}_{2} \mathrm{LT}$ hydrogen refuelings occurred at the CaFCP in West Sacramento, an hour drive from SFO which was subject to some difficult traffic delays depending on the time of day. In order to fill the unit more conveniently, an emerging supplier in mobile hydrogen delivery, IGX/GTM was contracted to deliver hydrogen to the $\mathrm{H}_{2} \mathrm{LT}$. IGX/GTM has developed a mobile refueling trailer (towed by pickup truck) with a capacity of $77 \mathrm{~kg} \mathrm{H}_{2}(99.95 \%$ pure) at $3600 \mathrm{psig}$. The provider of the hydrogen is Air Products.

Figure 26 shows a picture of the $\mathrm{H}_{2} \mathrm{LT}$ in use at SFO.

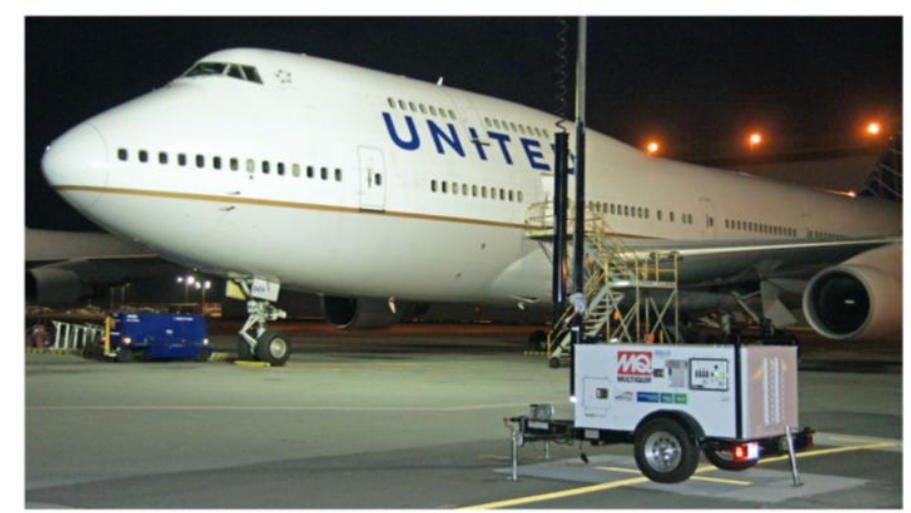

Figure 26: The $\mathrm{H}_{2} \mathrm{LT}$ illuminates the front of a United Airlines Boeing 747 parked near United's San Francisco Maintenance Operations Center at SFO. 
The unit at SFO was used to collect refueling data during IGX/GTM fills and also on one occasion at a hydrogen station. An initial cascade refueling test of the $\mathrm{H}_{2} \mathrm{LT}$ was performed on July 24, 2013, as shown in Figure 27, which was the first mobile refueling of an $\mathrm{H}_{2} \mathrm{LT}$ "in place" without it having to be removed from the field-test site. The pressure in the $\mathrm{H}_{2} \mathrm{LT}$ reached 3200 psig after about 10 minutes of refueling. Since this initial fill, IGX/GTM has become a certified vendor at SFO, making routine delivery of hydrogen to the $\mathrm{H}_{2} \mathrm{LT}$ via cascade fill.
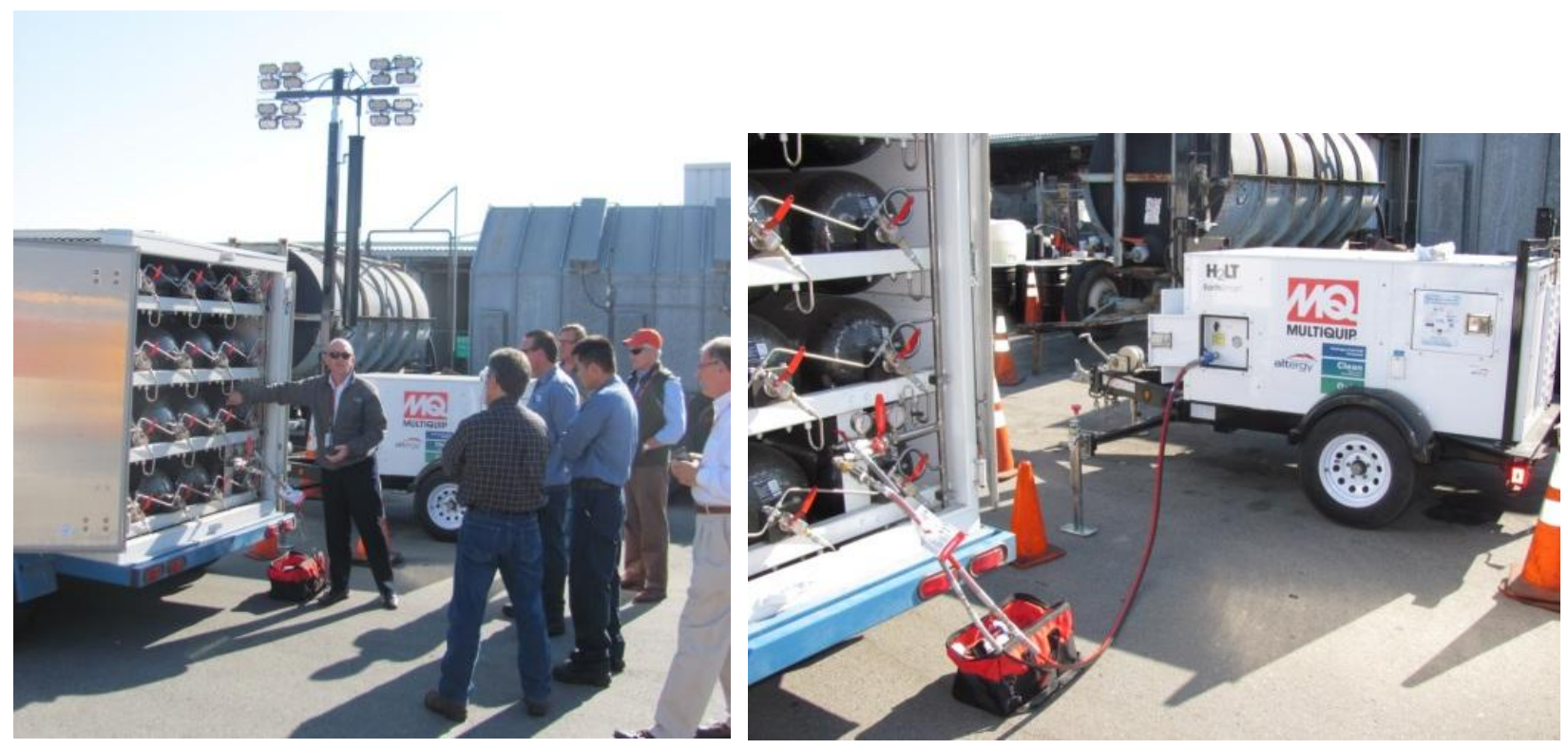

Figure 27: (L) Michael Koonce of IGX/GTM explains the mobile hydrogen refueling capability to SFO equipment staff. (R): The $\mathrm{H}_{2} \mathrm{LT}$ being refueled by cascade fill from the IGX/GTM in the SFO equipment yard on July 24, 2013.

During the second refueling of the system on October 3, 2013, data was collected to record the change in system pressure and temperature as the cascade fill proceeded. The temperature of the manifold dropped as hydrogen gas expanded (and cooled) into the $\mathrm{H}_{2} \mathrm{LT}$ tank volume. The results for the refueling are shown in Figure 28. During the cascade fill, the $\mathrm{H}_{2} \mathrm{LT}$ reached a pressure of $3150 \mathrm{psig}$ in $\sim 10 \mathrm{mins}$, corresponding to the transfer of $5.8 \mathrm{~kg}$ of hydrogen. The manifold temperature dropped quickly to $19^{\circ} \mathrm{F}\left(-7.2^{\circ} \mathrm{C}\right)$, due to cooling by the cold gas, but started to warm up thereafter due to compressive heating. At all times the temperature of manifold and valving remained above the $-40^{\circ} \mathrm{F}\left(-40^{\circ} \mathrm{C}\right)$ minimum temperature limit of the hardware. 


\begin{tabular}{|c|c|c|c|c|c|}
\hline $\begin{array}{l}\text { Time } \\
\text { (AM) }\end{array}$ & $\begin{array}{l}\mathrm{H}_{2} \mathrm{LT} \\
\text { Pressure } \\
\text { (psi) }\end{array}$ & $\begin{array}{l}\text { Valve } \\
\text { Temp. } \\
\left({ }^{\circ} \mathrm{F}\right)\end{array}$ & $\begin{array}{l}\text { Manifold } \\
\text { Temp. } \\
\left({ }^{\circ} \mathrm{F}\right)\end{array}$ & $\begin{array}{l}\text { Tank } \\
\text { Temp } \\
\left({ }^{\circ} \mathrm{F}\right)\end{array}$ & $\begin{array}{l}\text { Cascade } \\
\text { Tank No. } \\
\text { (on trailer) }\end{array}$ \\
\hline $9: 34$ & 30 & 57.7 & 71.7 & $\cdots$ & $\ldots$ \\
\hline $\begin{array}{c}9: 35 \\
\text { start fill }\end{array}$ & & & & & 1 \\
\hline $9: 38$ & 1350 & 32 & 19 & $\ldots$ & 1 \\
\hline $9: 42$ & 2200 & 39.4 & 38.4 & $\cdots$ & 2 \\
\hline $9: 44$ & 2700 & 48.3 & 48.4 & $\cdots$ & 3 \\
\hline $9: 48$ & 3000 & 57.7 & 56.9 & 97.3 & 3 \\
\hline $\begin{array}{c}9: 49 \\
\text { Stop fill }\end{array}$ & 3200 & 64.2 & 58.3 & 97.9 & $\ldots$ \\
\hline $\begin{array}{c}9: 52 \\
\text { top off }\end{array}$ & 3150 & 74.1 & 62.7 & 99.1 & 4 \\
\hline $9: 57$ & 3150 & 82.3 & 65.7 & 94.0 & $\ldots$ \\
\hline
\end{tabular}

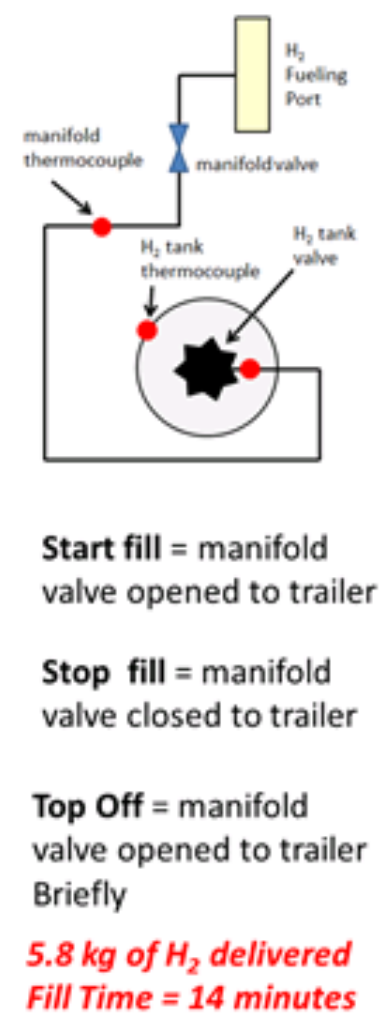

Figure 28: Measurements of $\mathrm{H}_{2} \mathrm{LT}$ hardware temperature and pressure during cascade fill of the system from the IGX/GTM mobile refueler. Conditions of the fill are as follows: Ambient air temperature $\sim 68^{\circ} \mathrm{F}\left(20^{\circ} \mathrm{C}\right)$, hydrogen temperature in the trailer $\sim 68^{\circ} \mathrm{F}$. Initial hydrogen pressure in the $\mathrm{H}_{2} \mathrm{LT}=30 \mathrm{psig}$. All four hydrogen tanks were open during fill. Five minutes of refueling trailer preparation time were required prior to the fill.

On one occasion, a Beta unit was filled at the A.C. Transit Hydrogen Station in nearby Emeryville California, which employs a SAE J2601 fill [10]. This particular J2601 fill involved pre-cooling of the hydrogen to $-4^{\circ} \mathrm{F}\left(-20^{\circ} \mathrm{C}\right)$ to reduce compression heating of the storage vessel. During this fueling $\sim 5 \mathrm{~kg}$ of hydrogen was delivered in $\sim 10$ minutes from an initial $\mathrm{H}_{2} \mathrm{LT}$ system pressure of $950 \mathrm{psig}$ to 5,000 psig. Thermocouple temperature measurements were made for the $\mathrm{H}_{2}$ Tank Valve and the Manifold as described above in Figure 28. Over the course of the fueling, the valve temperature dropped from $71^{\circ} \mathrm{F}$ to $32^{\circ} \mathrm{F}\left(21.66{ }^{\circ} \mathrm{C}\right.$ to $\left.0{ }^{\circ} \mathrm{C}\right)$, and the manifold temperature changed from $71^{\circ} \mathrm{F}$ to $6{ }^{\circ} \mathrm{F}\left(21.66^{\circ} \mathrm{C}\right.$ to $\left.-14.4{ }^{\circ} \mathrm{C}\right)$. Again, these temperature changes were above the $-40^{\circ} \mathrm{F}\left(-40^{\circ} \mathrm{C}\right)$ minimum temperature limit of the hardware. The lowest temperature was reached when the system was pressurized to $\sim 3,000 \mathrm{psig}$. Thereafter, compressive heating associated with bringing the system pressure to 5,000 psig brought the valve and manifold temperatures to $39^{\circ} \mathrm{F}\left(3.9^{\circ} \mathrm{C}\right)$ and $31^{\circ} \mathrm{F}\left(-0.55^{\circ} \mathrm{C}\right)$, respectively. It is worth noting that the Al-lined Type III SCI tanks used in this project have an upper temperature limit of $180^{\circ} \mathrm{F}\left(82.2^{\circ} \mathrm{C}\right)$, which is limited by the glass transition temperature of the 
composite overwrap. Such high temperatures were never approached during use of the SCI tanks in the project.

\section{Connecticut Department of Transportation, New Haven CT:}

In May of 2013, the $\mathrm{H}_{2} \mathrm{LT}$ was introduced to ConnDOT, as arranged by Greg Moreland, SRA International contractor to the DOE Fuel Cell Market Transformation Program. ConnDOT is engaged in the largest federally funded highway project currently being undertaken in the U.S, along Interstate I-95 at the intersection of I-91 in New Haven Connecticut [11]. ConnDOT was interested in field-testing a Beta $\mathrm{H}_{2} \mathrm{LT}$ to reduce emissions and noise in the work zone, allow ConnDOT to gain experience with fuel cells, promote $\mathrm{H}_{2}$ refueling in the area and display applications of fuel cells in transportation. On May 29, 2013, $\mathrm{H}_{2} \mathrm{LT}$ project and $\mathrm{H}_{2}$ safety seminars were delivered to transportation engineers in the ConnDOT Research Unit in Newington, CT, as well as to First Responders in the City of New Haven, as shown in Figure 29.

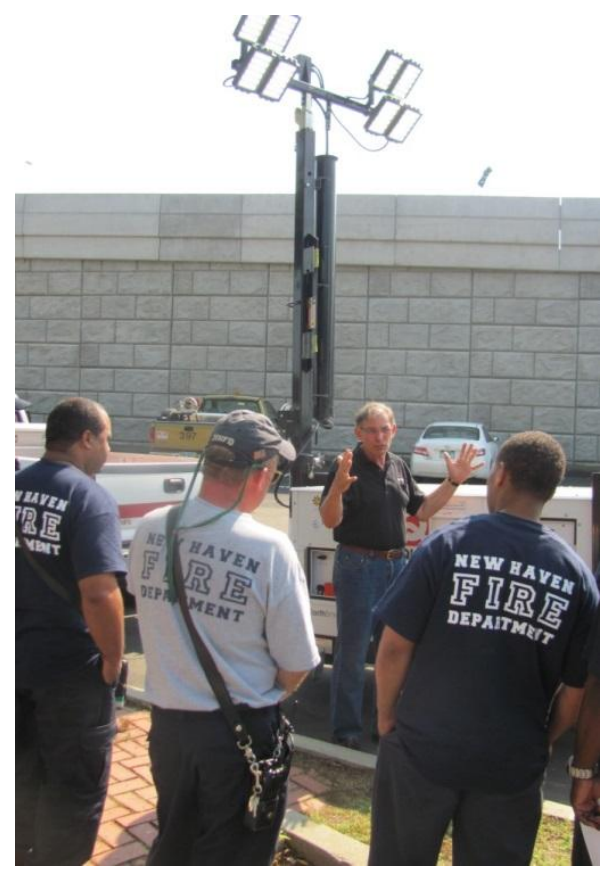

Figure 29: Mickey Oros of Altergy Systems explains the $\mathrm{H}_{2} \mathrm{LT}$ (outfitted with VisionX LED lights) to New Haven First Responders responsible for the I-95 construction project.

Later that same day, project descriptions were given to staff at the Proton SunHydro $\mathrm{H}_{2} \mathrm{Station}_{\text {in }}$ Wallingford Connecticut, where the unit would be refilled (17 miles from the construction site). At that meeting, SunHydro personnel trained the contractor construction staff from O\&G Industries Inc. on refueling the $\mathrm{H}_{2} \mathrm{LT}$. The overall field-test was under the local supervision of Rick Hanley of ConnDOT. 
The Beta $\mathrm{H}_{2} \mathrm{LT}$ was fitted with LED lights from VisionX that had the highest energy efficiency of lighting tested during the project. Figure 30 shows one of the eight VisionX fixtures used on the $\mathrm{H}_{2} \mathrm{LT}$. The fixture contains 30 individual LED bulbs, with reflector designed for a particularly forward-focused illumination pattern.

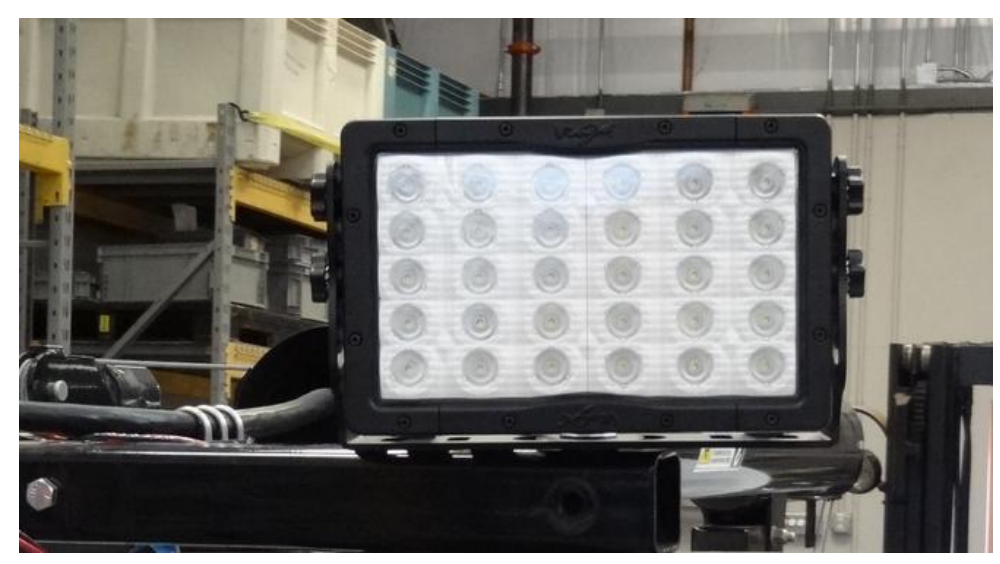

Figure 30: A VisionX LED fixture. There are eight such fixtures on the $B e t a \mathrm{H}_{2} \mathrm{LT}$ that was field-tested by ConnDOT in New Haven, CT.

The $\mathrm{H}_{2} \mathrm{LT}$ was inserted into ConnDOT operations on the night of May 29, 2013 and was used in a number of different night construction operations including general area lighting, and lighting for a pile-driving operation.

On September 28, 2013, feedback was collected from O\&G construction workers and inspectors who had been using the $\mathrm{H}_{2} \mathrm{LT}$. The workers found this particular $\mathrm{H}_{2} \mathrm{LT}$ configuration lacking in a number of areas, including light output and distribution, the inconvenience of refueling at a remote site (the Proton On-site station), the weight/balance of the $\mathrm{H}_{2} \mathrm{LT}$ and the absence of a $115 \mathrm{~V}$ AC auxiliary power supply on the unit. The workers were impressed with the low noise of the $\mathrm{H}_{2} \mathrm{LT}$, and its zero-emission performance.

This particular configuration of LED lights was deemed insufficient by the end-users in this application. Although the energy efficiency of the VisionX lights was quite high (54 lumens/watt), there were an insufficient number of fixtures on the unit to provide light that was satisfactory to the O\&G construction end-user. Furthermore, this particular LED reflector was designed to provide more forward-focused light, where in this ConnDOT application a wide illumination pattern was desired to illuminate a general work area (as opposed to a particular work task). After a couple of months of use, the unit was withdrawn from field-testing. The unit has since been re-directed to SFO for use, since SFO equipment staff had already evaluated this $\mathrm{H}_{2} \mathrm{LT}$ Beta unit, and found the illumination pattern and output well-suited to runway repair work. 
This difference between end-user requirements for lighting highlights the need for MQ to offer multiple lighting configuration options for the commercial $\mathrm{H}_{2} \mathrm{LT}$.

The official field-tests of the $\mathrm{H}_{2} \mathrm{LT}$ ended on January 20, 2014, coinciding with the end of the project. However, two Beta $\mathrm{H}_{2}$ LT units will continue to be used and supported by SFO, with mobile refueling from IGX/GTM. In addition, the Alpha $\mathrm{H}_{2} \mathrm{LT}$ and a Beta $\mathrm{H}_{2} \mathrm{LT}$ will continue to be used and supported by Saunders Electric in their entertainment industry work. Thus, two enduring fleets of $\mathrm{H}_{2} \mathrm{LT}$ units will continue in 2014 and beyond, reducing GHG emission in aviation GSE and construction equipment. MQ and Altergy will continue to support these fleets as arranged by SFO and Saunders Electric.

\section{Design Lessons Derived from Field Tests of the $\mathrm{H}_{2} \mathrm{LT}$ :}

During the $\sim 3$ years of field testing, the end-users provided valuable feedback on how to improve the $\mathrm{H}_{2} \mathrm{LT}$ design. In addition, a number of maintenance issues arose that point to areas needing improvement to provide a truly robust commercial product. The largest of these "design lessons" are now reviewed.

One of the major issues that arose from the field tests is unreliability in the plasma light technology in applications where the lighting system is moving. Although the technology was known to be reliable in stationary applications such as street lighting, in the mobile $\mathrm{H}_{2} \mathrm{LT}$ the plasma fixtures failed in unacceptable numbers. The cause of the problem is believed to be a motion-induced misalignment between the plasma in the plasma light bulb and the RF waveguide when the lamp is on, which causes RF energy to reflect back into the RF driver, damaging the driver electronics. The straightforward solution to this problem was to discontinue use of the plasma lights, and introduce LED technology in the latter stages of the project. LED lights have progressed enormously in the 3 year timeframe of the project, offer higher efficiency than plasma lights, instant on/off capability and are more robust. Our testing of the LED technology indicates it is sufficiently robust for the $\mathrm{H}_{2} \mathrm{LT}$ application, consistent with LED technology already being used in mobile applications such as automobiles and other mobile equipment.

Another major issue was the reliability of the manual multi-turn tank valves on the composite hydrogen tanks. Six of the 22 manual multi-turn tank valves on $\mathrm{H}_{2} \mathrm{LT}$ units became stuck after 3 years of service. Typically the valve stem seized in the closed position. In two cases, the valves could be freed up, with the valve stem lubricated externally to prevent re-occurrence of the problem. However, in the other four cases, the valve could not be repaired in the field. These valve problems did not produce a hydrogen leak, did not involve contamination of the hydrogen fuel, nor had adverse impact on fuel cell integrity. However, these valve failures interfered with $\mathrm{H}_{2} \mathrm{LT}$ refueling. A multi-turn valve is not needed for the $\mathrm{H}_{2} \mathrm{LT}$ application, since only a 1/4-turn valve rated for $6500 \mathrm{psig}$ hydrogen service is needed. MQ will be using a 1/4-turn manual ball valve such as that provided by Oasis Valve (Model T104) for the commercial $\mathrm{H}_{2} \mathrm{LT}$. 
Table III summarizes additional reliability issues that surfaced during the $\mathrm{H}_{2} \mathrm{LT}$ field tests, and the corrective action being undertaken for the commercial $\mathrm{H}_{2} \mathrm{LT}$ design.

Table III: Additional reliability issues with the $\mathrm{H}_{2} \mathrm{LT}$, with design solutions.

\section{The Problem}

1. Fuel Cell voltage tap connections can come loose with vibration.

\section{The Design Solution}

The voltage taps on the Altergy PEM fuel cell were re-designed to make it impossible to shake loose with vibration

MQ will position the purge line in the commercial $\mathrm{H}_{2} \mathrm{LT}$ so it cannot be pinched closed.

Commercial $\mathrm{H}_{2} \mathrm{LT}$ will have a more corrosion-resistant winch

Grounding issues between the DC/AC inverter and the fuel cell caused the problem and were resolved. The commercial $\mathrm{H}_{2} \mathrm{LT}$ will incorporate the design change.

The commercial $\mathrm{H}_{2} \mathrm{LT}$ will have a prominent "system power on" light to remind users the system is on in the daytime.

The commercial unit will have the FC waste heat vents on the side of the enclosure.

The balance issue will be addressed in the commercial $\mathrm{H}_{2}$ LT final design

More robust cabinet lock systems will be installed on the commercial $\mathrm{H}_{2} \mathrm{LT}$ unit. insufficient to withstand cold weather conditions 
9. A pivot point on the $\mathrm{H}_{2} \mathrm{LT}$ tower mast became corroded during 1-year field test at the NASA KSC
NASA recommends applying a zinc-based sacrificial coating to the frame under the black powder coating to prevent corrosion.

\section{Relationship to Other Work and Products}

During the course of this project, we became aware of related activities in the effort to bring fuel cell power to portable lighting. Recently, BOC developed a small fuel cell mobile lighting system using hydrogen as the fuel source [12]. The BOC product operates in a very different regime of power and lighting output than the $\mathrm{H}_{2} \mathrm{LT}$. The $\mathrm{H}_{2} \mathrm{LT}$ has a $5000 \mathrm{~W}$ Altergy fuel cell, compared to the $150 \mathrm{~W}$ fuel cell in the BOC. The $\mathrm{H}_{2} \mathrm{LT}$ stores $8.4 \mathrm{~kg}$ of hydrogen, compared to the $0.18 \mathrm{~kg}$ stored by the BOC hydrogen cylinder (which itself weighs $10 \mathrm{~kg}$ ). Also, the $\mathrm{H}_{2} \mathrm{LT}$ is designed to output the equivalent of $\sim 4000 \mathrm{~W}$ of conventional lighting power for 66 hours, compared to the $\sim 600 \mathrm{~W}$ of lighting power by the BOC unit which advertises duration of 24 hours. So, the two units are designed for very different tasks. The Multiquip $\mathrm{H}_{2} \mathrm{LT}$ is designed for large area, long endurance lighting; the BOC unit for small area, shorter duration lighting. Since both are useful tasks, it is gratifying to see fuel cell proliferation in these different power regimes of portable equipment.

After our demonstration of the $\mathrm{H}_{2} \mathrm{LT}$ at the 2009 AASHTO meeting, we became aware of unpublished work from 2006 in which Bowman and colleagues [13] at the Jet Propulsion Laboratory (JPL) proposed a fuel cell mobile lighting system for a U.S. Air Force demonstration. The proposed unit was based on a retrofit to a Unicore NF-2D Floodlight Set (i.e., a light cart), with a metal hydride hydrogen storage system storing $1 \mathrm{~kg}$ of hydrogen integrated to a 2 - $4 \mathrm{~kW}$ liquid cooled fuel cell. Such a system was demonstrated at Hickam Air Force Base in Hawaii by Hawaii Hydrogen Carriers LLC.

\section{Next Steps Toward Commercialization:}

With the field-tests results completed, and a wealth of information garnered from the end-user feedback across all 5 field-test sites, MQ is in the process of redesigning the commercial system to reduce cost while maintaining performance. With the rapid increase in the energy efficiency (lumens/watt) of LED technology, the commercial $\mathrm{H}_{2} \mathrm{LT}$ system does not need a $5 \mathrm{~kW}$ fuel cell as it was configured during the project. A lighting power draw of $\sim 2 \mathrm{~kW}$ should be sufficient for most lighting applications, indicating that unless an end-user needs large amounts of auxiliary power, then the system could be built using a less expensive $\sim 2.5 \mathrm{~kW}$ PEM fuel cell. Sandia has recommended to MQ that the commercial system be based on 3600 psig hydrogen tank technology. Filling a unit to 3600 psig would provide $75 \%$ of the hydrogen storage 
accommodated by 5000 psig storage technology. The duration of the Beta $\mathrm{H}_{2} \mathrm{LT}$ equipped with the VisionX LED lights was typically $\sim 85$ hours when the unit was filled to 5000 psig. The runtime with 3600 psig hardware would be $\sim 60$ hours, still a very good duration. The cost of the system hardware (tanks, valves, etc.) for 3600 psig hydrogen service would be about half the cost of hardware rated for 5000 psig. By reducing costs for the fuel cell, and the hydrogen storage system, the price of the unit (including markup), originally estimated to be $\sim \$ 50 \mathrm{~K}$, could be reduced to a more acceptable $\sim \$ 35 \mathrm{~K}$ per unit. Other approaches to reducing $\mathrm{H}_{2} \mathrm{LT}$ system cost even further are currently being evaluated by MQ. In the course of showing the technology at trade shows, the system was quoted to hundreds of potential customers in the U.S. and Canada, but the $\sim \$ 50 \mathrm{~K}$ selling price was identified as a barrier to purchase.

By going to a system based on 3600 psig pressure, the $\mathrm{H}_{2} \mathrm{LT}$ technology would not need to rely on the very few existing $\mathrm{H}_{2}$ stations to be fueled. Such stations will be gradually coming to the U.S. as fuel cell electric vehicles (FCEVs) gradually roll out. Instead, the units could be very conveniently refilled today using the 3600 psig mobile refueling technology such as that developed by IGX/GTM, and which is now in routine use at SFO. Mobile refueling is the nearterm future for a piece of fuel-cell-based portable equipment such as the $\mathrm{H}_{2} \mathrm{LT}$. Alternatively, the $\mathrm{H}_{2} \mathrm{LT}$ unit could be fueled from commercially available (but more expensive) bottled hydrogen at 2300 psig, with a booster pump increasing the pressure to $3600 \mathrm{psig}$.

The Fuel Cell Mobile Light project has shown that PEM fuel cells and associated hydrogen hardware are sufficiently robust for the mobile light application. The durability of the technology was unknown going into the project, as fuel cells had never before been subjected to the harsh conditions involved in the field-tests. The field-tests also revealed that the end-user enjoys how quiet the technology is, and its zero-emissions rating. The system can be used in a wide variety of applications from entertainment, to road construction, and many applications inbetween. Commercializing the system will require getting the system cost down, with MQ's approach being to reduce the fuel cell power, and lower the system pressure rating. MQ must also find the right combination of LED lighting technology options that are flexible enough to meet the varying (and sometimes conflicting) demands of the customer on illumination pattern and total light output, while maintaining high lumen/watt energy efficiencies. The future looks bright as LED lighting technology continues to rapidly advance and come down in price as well.

Fuel availability is a commercialization concern for MQ, as neither mobile hydrogen refueling nor stationary hydrogen stations are currently widespread. Light-duty FCEVs are coming, and their introduction in large numbers will be a rising tide lifting all boats from a hydrogen availability and infrastructure point of view, allowing lower-cost mobile hydrogen refueling at 3600 psig as well. Even though the initial $\mathrm{H}_{2} \mathrm{LT}$ units would be geared to mobile refueling at 3600 psig (to reduce costs), the $\mathrm{H}_{2} \mathrm{LT}$ can easily incorporate higher-pressure composite tank technology (as was the case for the Alpha and Beta $\mathrm{H}_{2} \mathrm{LT}$ units). With the move to 700 bar hydrogen stations to support FCEVs, when such stations became truly widespread, MQ would need to increase the pressure rating of its storage tanks beyond the 350 bar tanks used in this 
project to fuel at such stations. Before the $\mathrm{H}_{2} \mathrm{LT}$ can be truly sold on a wide scale, more hydrogen fueling (mobile, stationary) infrastructure will have to be developed. Multiquip is committed to commercializing the technology, but sales of the $\mathrm{H}_{2} \mathrm{LT}$ limited to major markets only with current fuel availability is not sufficient for a successful product launch. In the meantime, in 2014, MQ will redesign the $\mathrm{H}_{2} \mathrm{LT}$ system for lower fuel cell power and lower pressure rating, determine the most desirable LED lighting packages, while driving down the $\mathrm{H}_{2} \mathrm{LT}$ system cost to as low as possible.

\section{Reception of the Technology by the Construction Equipment Community}

During the early phases of the field-testing, MQ showed the $\mathrm{H}_{2} \mathrm{LT}$ technology to its power generation and construction equipment customers in order to gauge potential customer interest in the technology. The $\mathrm{H}_{2} \mathrm{LT}$ technology was first shown at a power technology trade show on December 15, 2010 at PowerGen in Orlando Florida. Before the show, the Orlando Convention Center Fire Marshall was briefed on the $\mathrm{H}_{2} \mathrm{LT}$ technology and the physical properties of hydrogen gas, by the CaFCP, Altergy and Sandia. After the briefing, permission was granted to operate the unit indoors. The $\mathrm{H}_{2} \mathrm{LT}$ was the only piece of power generation equipment allowed to run inside the convention center (diesel equipment is forbidden to be run indoors at such facilities). Figure 31 shows the operating Alpha $\mathrm{H}_{2} \mathrm{LT}$ at this first trade show appearance.

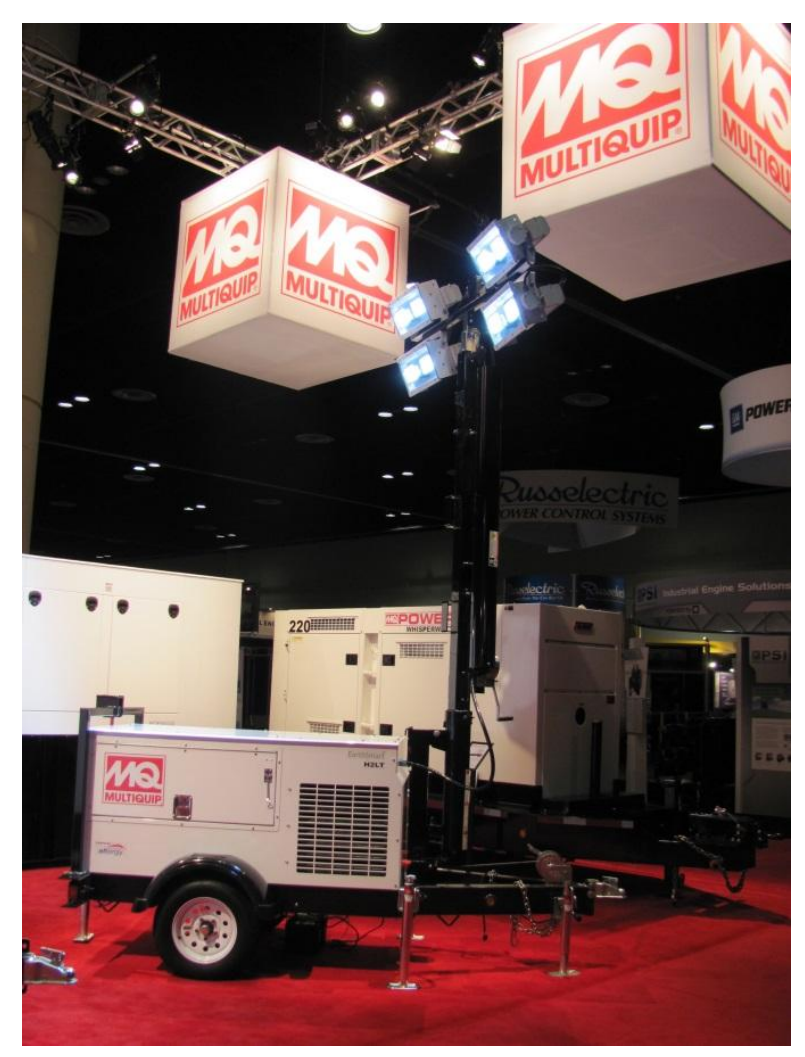


Figure 31: The first appearance of Alpha $\mathrm{H}_{2} \mathrm{LT}$ technology at PowerGen 2010, December 15, 2010, Orlando Convention Center in Orlando Florida.

Similarly, the Beta $\mathrm{H}_{2} \mathrm{LT}$ was first shown at the World of Concrete Trade Show on January 19, 2011 at the Las Vegas Convention Center. Prior to the show, the Las Vegas Convention Center Fire Marshall was also briefed on the $\mathrm{H}_{2} \mathrm{LT}$ technology and hydrogen properties as they relate to safety issues. After the briefing, permission was granted to operate the unit indoors. Figure 32 shows Torsten Erbel of Multiquip being interviewed about the Beta $\mathrm{H}_{2} \mathrm{LT}$ technology at the World of Concrete show on January 19, 2011 in Las Vegas Nevada.

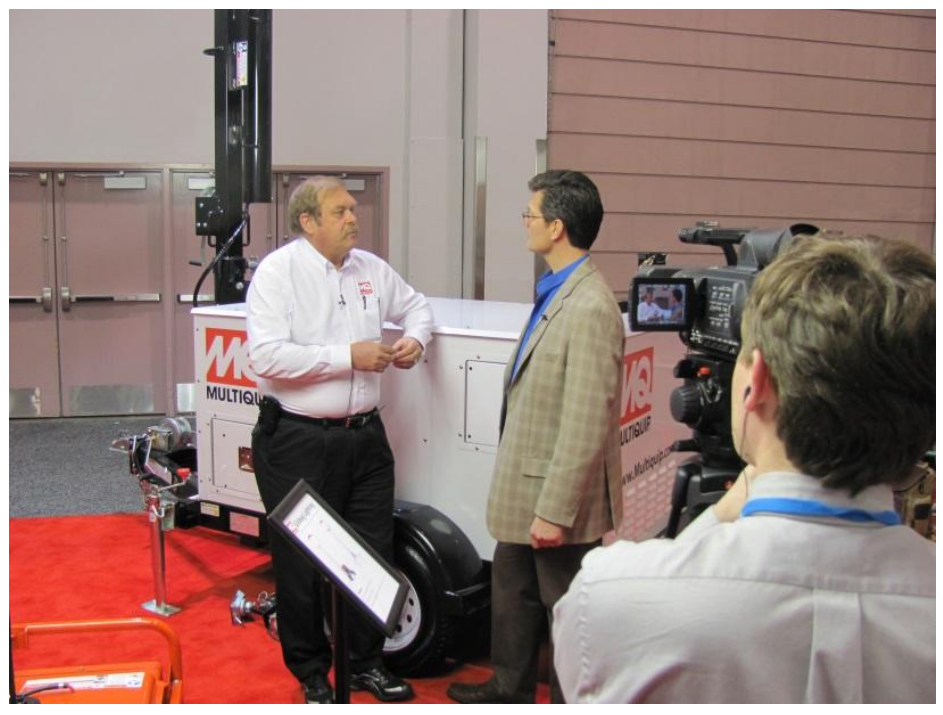

Figure 32: Torsten Erbel of MQ (left) being interviewed about the Beta $\mathrm{H}_{2} \mathrm{LT}$ unit being shown for the first time at the World of Concrete Show, January 19, 2011, Las Vegas Convention Center, Las Vegas Nevada.

The reception given the technology at these shows by the all-important customer base was very positive. The $\mathrm{H}_{2} \mathrm{LT}$ project and technology has received recognition from the rental and construction equipment industries, as well as from the DOE and from U.S. Federal Technical Transfer Organizations. These recognitions include:

1. 2011 Rental Equipment Magazine "Grand Prize" for Innovative Technology, December 20, 2011;

2. "Editor's Choice Award" for Most Innovative New Product in "General Equipment," World of Concrete 2011, February 15, 2011; 
3. 2011 DOE Hydrogen and Fuel Cells Program R\&D Award, "In recognition outstanding contributions to Fuel Cell Market Transformation Activities," May 11, 2011;

4. 2012 Federal Laboratory Consortium (FLC) National Award for Excellence in Tech Transfer, May 3, 2012;

5. 2010 Federal Laboratory Consortium Award "Mid-Continent Region" for "Notable Technological Achievement", September 2010.

The $\mathrm{H}_{2} \mathrm{LT}$ received a U.S. Patent in 2013 [14].

\section{Impressions of this Fuel Cell Market Transformation Project from the Industrial Participants:}

For many of the industrial participants, this project was a new experience, not only in a technical sense (creating a new product based on hydrogen fuel cell technology), but also in the way the project was organized, funded and executed. The industry partners found it to be a very effective way of partnering together. Altergy's experience was very positive, because the project had:

1. Top echelon partners in their respective field of responsibility

2. A very professional team with an open exchange of data

3. A "team first" approach philosophy within the group, with no guarding of turfs.

Altergy would not have pursued fuel cells in the construction market were it not for this project, an indeed, the $\mathrm{H}_{2} \mathrm{LT}$ platform opened up further product opportunities that were not originally anticipated.

From Multiquip's perspective, the Fuel Cell Mobile Light project had a "profound" effect on the company. In particular, the project:

1. Exposed and entered the company into a technology MQ would not have otherwise pursued.

2. Created a new technology platform (Earthsmart ${ }^{\mathrm{TM}}$ ) within MQ.

3. Added new product lines to MQ's offerings.

4. Generated acknowledgement from the construction field for innovative thinking.

5. Gave MQ the opportunity to work with leading companies and gain knowledge from their expertise. It was a wonderful experience for the company's team members.

6. It broadened MQ's view and exposed MQ to the benefits of working outside the company on a development project, gaining many new friends and business partners and an enormous amount of support. 
We believe this project broke new ground on how a large group of entities with a shared genuine concern about GHG emissions can come together to accelerate the introduction of hydrogen fuel cell technology into new markets.

\section{Conclusions:}

A project was described to introduce hydrogen PEM fuel cell technology into aviation GSE and rental construction equipment. The $\mathrm{H}_{2} \mathrm{LT}$ fuel cell mobile light tower combines hydrogen stored as a high-pressure gas, a $5 \mathrm{~kW}$ PEM fuel cell and advanced lighting into a single unit with uses in aviation and construction. A 15-institution project team was assembled, bringing together new technology expertise (hydrogen and fuel cells), equipment mass manufacturing capability (mobile lights, lighting) and influential end-users who could field test the $\mathrm{H}_{2} \mathrm{LT}$ in real-world use in diverse environments and provide feedback for design improvement. Prototype units were constructed and field tested in the entertainment industry, with SFO, the NASA KSC, Caltrans, and with ConnDOT. These field tests allowed us to assess the durability of the $\mathrm{H}_{2} \mathrm{LT}$ technology in a wide variety of potentially corrosive environments (cold/wet, hot/humid/salt-air) while performing a wide variety of tasks. At the same time the $\mathrm{H}_{2} \mathrm{LT}$ reduced diesel emissions at the field-test sites and helped to promote hydrogen PEM technology in new influential markets. The $\mathrm{H}_{2} \mathrm{LT}$ proved to be exceptionally durable in these diverse environments, demonstrating the compatibility of PEM fuel cells and high-pressure hydrogen storage with the construction equipment application. The field tests produced data on system performance (efficiency, duration, GHG reductions), the ease of refueling the system by different methods $\left(\mathrm{H}_{2}\right.$ stations, mobile refueling), and feedback assessing the $\mathrm{H}_{2} \mathrm{LT}$ performance in different and often difficult lighting tasks. The $\mathrm{H}_{2} \mathrm{LT}$ system was compared directly to a comparable diesel-fueled light tower with regard to size, performance and emissions. Overall, end users were pleased with the performance, noting the lack of emissions and exceptionally low noise level. LED lighting was found to be the most energy efficient and robust lighting technology for the $\mathrm{H}_{2} \mathrm{LT}$ application. The technical "lessons-learned" are being folded into the final $\mathrm{H}_{2} \mathrm{LT}$ design for commercialization by Multiquip Inc. The industrial participants found the project to be a very effective way of working together to reduce GHG emissions in the aviation GSE and construction equipment markets, and to accelerate the introduction of hydrogen fuel cell technology into these new markets.

\section{Acknowledgements:}

It is with great pleasure that the authors acknowledge the contributions of many who made this project possible. Very early encouragement of the project from Jay Keller, former lead of the Hydrogen Program at Sandia National Laboratories, was critical for the early success of the project. Continuing support and encouragement from Tom Felter and Joe Pratt at Sandia is deeply appreciated. 
Partial funding from the Boeing Company is gratefully acknowledged via the Boeing/Sandia CRADA SC02/1651.14.00. Funding from the Fuel Cell Market Transformation program (led by Pete Devlin) at the U.S. DOE Fuel Cell Technologies Office was critical, making the broader and stronger development project possible, and specifically allowing the construction and field testing of five additional $\mathrm{H}_{2} \mathrm{LT}$ units. In addition to funding, we appreciate the encouragement of Pete and his colleagues Nancy Garland and John Christensen in the Market Transformation program. Special thanks to Sunita Satyapal at DOE for supporting this work. The authors thank Tien Nguyen of DOE for providing an analysis of GHG emissions for the $\mathrm{H}_{2} \mathrm{LT}$ technology, with the hydrogen derived from either steam reforming of natural gas, or wind-based electrolysis of water.

Jonathan Cuppett, Juan Quiros and Bob Apuzzo at MQ assisted with many of the field tests of the $\mathrm{H}_{2} \mathrm{LT}$, for which the authors are grateful. We acknowledge the superb support MQ received from Norco Inc. staff Ken Goicoechea and Roger Hudgens, both gas manufacturing plant operations managers with over 20 years' experience in the gas production business. Ken and Roger played a vital role in the system leak checking and final pressure certification of every $\mathrm{H}_{2} \mathrm{LT}$ unit leaving the Boise Idaho MQ manufacturing facility.

The project would not have been successful without the participation of Caltrans. We thank Randy Iwasaki, former director of Caltrans, for providing wonderful encouragement and support of the work in its early phases, and offering resources of the Division of Research and Innovation at Caltrans (under the direction of Larry Orcutt) to be applied in support of the project. Larry Orcutt directed Nancy Chinlund of Caltrans to become involved. Nancy was very proactive in launching the project from a Caltrans perspective, which led directly to Randy Woolley's involvement in the project. The Caltrans partners aggressively challenged the project to build a prototype in a few months' time to be shown at the 2009 AASHTO meeting.

Caltrans provided considerable in-kind support through the donation of its own technical expertise, but also through its support of the U.C. Davis AHMCT for characterizing the lighting options for the $\mathrm{H}_{2} \mathrm{LT}$ as well as supervising the Caltrans District 3 field test. We acknowledge the contributions of Gonzalo Gomez of Caltrans for discussions of lighting technology options for the $\mathrm{H}_{2} \mathrm{LT}$. Ben Creed, Lauren Miller, Sean Donohoe and Matt Jones at U.C. Davis provided many hours of night work characterizing the illumination provided by the candidate plasma, LED and MH lighting options. In a related activity, Ty Larson of Boeing performed checks that the glass covering the plasma lights was sufficiently absorbing UV radiation, which was very helpful.

The staff at Saunders Electric, including Ron Brewer, Frank Soggiu and Pat Hess were instrumental in the 3-year field tests of the Alpha and Beta $\mathrm{H}_{2} \mathrm{LT}$ units used for the Los Angeles entertainment award shows and elsewhere in the entertainment industry. 
The field test of the unit at the NASA KSC was an excellent example of cooperation between government agencies. We thank Chuck Griffin for providing local supervision of the project from the NASA KSC end, along with a lot of help from Melissa Clevenger of the propellants group and Ray Davis from operations. The KSC staff were extremely professional and helpful. We thank Pattie Lewis Burford (ITB Inc.) and Jerry Curran (EASI) for providing corrosion inspection of the Beta unit that was field tested at the NASA KSC for a year, and Randy Morris for extensive coordination.

A number of folks associated with ConnDOT and its contracting partner O\&G Industries were instrumental in the field testing in New Haven CT. While Rick Hanley of ConnDOT oversaw the field test of the unit at the Q-bridge construction project along I-95 in New Haven, Joe Hudach was the lead engineer from O\&G Industries managing the $\mathrm{H}_{2} \mathrm{LT}$ use at the construction site. We thank Larry Moulthrop and colleagues at the Proton SunHydro $\mathrm{H}_{2} \mathrm{Station}$ in Wallingford CT for providing refueling services for the $\mathrm{H}_{2} \mathrm{LT}$ during its deployment in New Haven CT.

A number of people and institutions facilitated various field tests during the project, in some cases donating needed hydrogen. We thank Polo del Toro and Bill Loper of the Sunline Hydrogen Station in Palm Desert CA for donating hydrogen in support of the 2009 AASHTO showing of the Alpha Unit. The authors thank Dan Rabun and Andrew Youlio of Air Products who provided refueling training to Saunders Electric staff during the early field-tests of the unit at the 2010 Academy Awards for which a mobile hydrogen station was rented and located at the Saunders Electric equipment yard in Arleta CA. Dan Poppe and the Burbank Hydrogen Station was a hydrogen vendor for several early entertainment field tests. Later, Rick Sikes and his staff at the Santa Monica Hydrogen Station donated hydrogen to the cause and provided refueling for the $\mathrm{H}_{2} \mathrm{LT}$ field tests at many entertainment award events in Los Angeles, CA.

Nico Bouwkamp and Jordan McRobie of the CaFCP are acknowledged for connecting the project with the Sunline Hydrogen Station and the Santa Monica Hydrogen Station, respectively. During deployment of the $\mathrm{H}_{2} \mathrm{LT}$ in Caltrans District 3, the $\mathrm{H}_{2} \mathrm{LT}$ unit was refueled at the hydrogen station on the property of the $\mathrm{CaFCP}$. We thank the refueling staff at the $\mathrm{CaFCP}$ for many trouble-free refueling events.

Special thanks are extended to Mark Bauserman, former Chief Engineer of Paramount Pictures. Mark "got" the $\mathrm{H}_{2} \mathrm{LT}$ concept very quickly, and was instrumental in connecting the project to the entertainment world, and advising us on ways the technology could be most fruitfully used in that realm of application. Mark hosted the showing of the $\mathrm{H}_{2} \mathrm{LT}$ on Stage 17 at Paramount on January 14, 2010, and arranged for Saunders Electric to attend, as well as many technology representatives from Hollywood studios. 
Thanks are extended to Jaimie Levin (formerly of A.C. Transit), Steve Eckhardt (formerly of Linde) and Nitin Natesan of Linde for providing the SAE J2601 fill of the $\mathrm{H}_{2} \mathrm{LT}$ at the Emeryville CA hydrogen station, and to DeLisa Leighton at IGX/GTM who coordinated multiple refuelings of the $\mathrm{H}_{2} \mathrm{LT}$ units at SFO using the IGX/GTM mobile hydrogen refueler. We acknowledge many helpful conversations and excellent project support concerning the composite hydrogen tanks from John Coursen of Structural Composites Industries.

Finally, Lennie Klebanoff would like to thank Woody Clark for many interesting and supportive conversations concerning fuel cell technology and entertainment environmental activities.

Woody also helped to promote the technology in his contacts and work in the Los Angeles area, which is very much appreciated.

Figure 33 shows some of the participants acknowledged above involved with the field-testing of the $\mathrm{H}_{2} \mathrm{LT}$. Unless indicated otherwise, all photographs appearing in this paper are courtesy of L.E. Klebanoff.

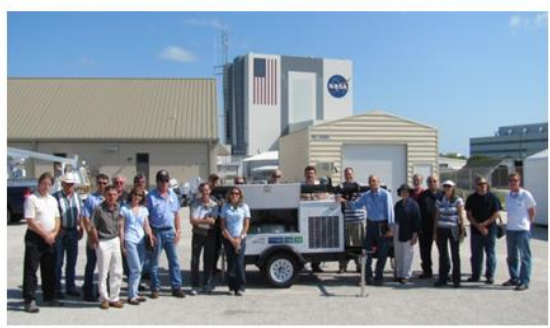

NASA KSC

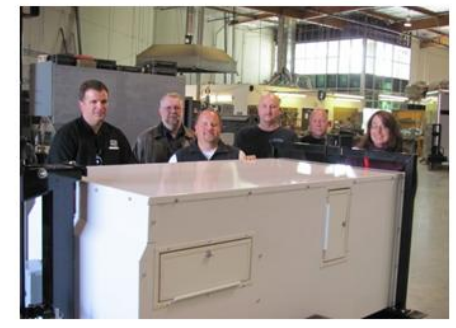

Saunders Electric, Inc.

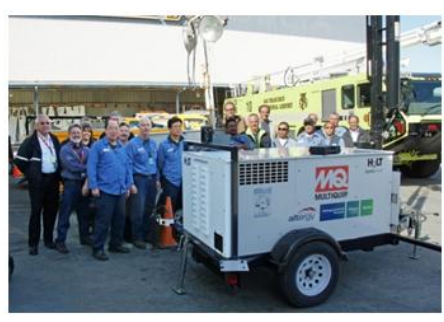

SFO

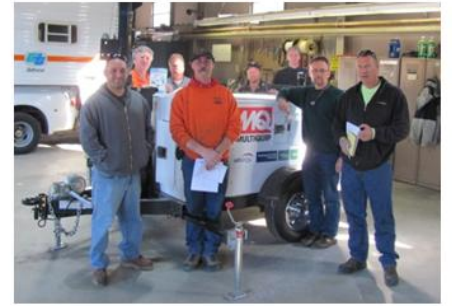

Caltrans District 3

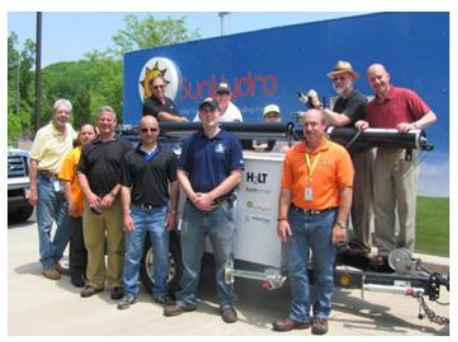

ConnDOT

Figure 33: End-users who participated in the field tests of the $\mathrm{H}_{2} \mathrm{LT}$.

Sandia National Laboratories is a multi-program laboratory managed and operated by Sandia Corporation, a wholly owned subsidiary of Lockheed Martin Corporation, for the U.S. Department of Energy's National Nuclear Security Administration under contract DE-AC0494AL85000. 


\section{References:}

[1]. J. Keller, L. Klebanoff, S. Schoenung and M. Gillie, "The Need for Hydrogen-based Energy Technologies in the 21st Century, Chapter 1 in Hydrogen Storage Technology, Materials and Applications, Ed. L.E. Klebanoff (Boca Raton: Taylor \& Francis; 2012), p. 3.

[2]. L. Klebanoff, J. Keller, M. Fronk and P. Scott, "Hydrogen Conversion Technologies and Automotive Applications," Chapter 2 in Hydrogen Storage Technology, Materials and Applications, Ed. L.E. Klebanoff (Boca Raton: Taylor \& Francis; 2012), p. 31.

[3] L.E. Klebanoff and C. Cornelius, "Analysis of Hydrogen Storage for a Fuel Cell Emergency Power System (FCEPS) for Commercial Aircraft", Final Project Report to Boeing, July 18, 2007 SAND Report No. SAND2007-4542P.

[4]. W. White, L.E. Klebanoff and S. Velinsky, in preparation.

[5]. R. Reid and A. Pradham, LD\&A, October 2011, page 56.

[6]. C. Song, L.E. Klebanoff, T.A. Johnson, et al. "Using Metal Hydride $\mathrm{H}_{2}$ Storage in Mobile Fuel Cell Equipment: Design and Predicted Performance of a Metal Hydride Fuel Cell Mobile Light," submitted to the International Journal of Hydrogen Energy.

[7]. C. Sloane, "Codes and Standards for Hydrogen Storage in Vehicles," Chapter 12, in "Hydrogen Storage Technology, Materials and Applications," Ed. L.E. Klebanoff (Taylor and Francis, Boca Raton 2012), p. 405.

[8]. GHG estimates courtesy of Tien Nguyen (DOE FCTO) who provided calculations of total energy associated with producing and delivering diesel fuel, as well as hydrogen from Natural Gas (NG) and renewable methods (wind-based electrolysis), along with the appropriate GHG emissions associated with the relevant production and delivery paths. The calculations were based on the Argonne GREET Model https://greet.es.anl.gov/, and a report from the National Renewable Energy Laboratory (NREL) http://www.nrel.gov/docs/fy10osti/46612.pdf .

[9]. Lead-acid battery gravimetric and volumetric stored energies taken from data provided for the Trojan T-1275 flooded $12 \mathrm{~V}$ lead-acid battery, product of the Trojan Battery Company.

[10]. A description of the SAE J2601 hydrogen fueling protocol for light-duty vehicles can be found at: http://www.energy.ca.gov/contracts/notices/2012-0710_workshop/presentations/SAE_Jesse_Schneider_Fueling_Protocol.pdf

[11]. Q-bridge construction project is described at: http://www.i95newhaven.com/\# [12]. http://www.boconline.co.uk/en/news-and-media/press_releases/news2012-11-01.html 
[13]. R. C. Bowman, Jr., P.R. Wilson, and J.W. Reiter, "Conceptual Design Study of Hydride Storage for Fuel Cell Power Systems in USAF Applications," Final Report to Advanced Power Technology Office (APTO), January 31, 2006.

[14]. "Mobile Lighting Apparatus,” G. Roe, L.E. Klebanoff et al., U.S. Patent No. 8,439,534, Issued May 14, 2013. 